\title{
Review
}

\section{Solid State NMR Spectroscopy a Valuable Technique for Structural Insights of Advanced Thin Film Materials: A Review}

\author{
Mustapha El Hariri El Nokab ${ }^{1}$ (D) and Khaled O. Sebakhy ${ }^{2, *(D)}$ \\ 1 Zernike Institute for Advanced Materials, University of Groningen, Nijenborgh 4, \\ 9747 AG Groningen, The Netherlands; m.el.hariri.el.nokab@rug.nl \\ 2 Engineering and Technology Institute Groningen, University of Groningen, Nijenborgh 4, \\ 9747 AG Groningen, The Netherlands \\ * Correspondence: k.o.sebakhy@rug.nl; Tel.: +31-629928542
}

Citation: El Hariri El Nokab, M.; Sebakhy, K.O. Solid State NMR Spectroscopy a Valuable Technique for Structural Insights of Advanced Thin Film Materials: A Review.

Nanomaterials 2021, 11, 1494.

https: / / doi.org/10.3390/

nano11061494

Academic Editor: Alessandro Barge

Received: 9 May 2021

Accepted: 2 June 2021

Published: 4 June 2021

Publisher's Note: MDPI stays neutral with regard to jurisdictional claims in published maps and institutional affiliations.

\begin{abstract}
Solid-state NMR has proven to be a versatile technique for studying the chemical structure, 3D structure and dynamics of all sorts of chemical compounds. In nanotechnology and particularly in thin films, the study of chemical modification, molecular packing, end chain motion, distance determination and solvent-matrix interactions is essential for controlling the final product properties and applications. Despite its atomic-level research capabilities and recent technical advancements, solid-state NMR is still lacking behind other spectroscopic techniques in the field of thin films due to the underestimation of NMR capabilities, availability, great variety of nuclei and pulse sequences, lack of sensitivity for quadrupole nuclei and time-consuming experiments. This article will comprehensively and critically review the work done by solid-state NMR on different types of thin films and the most advanced NMR strategies, which are beyond conventional, and the hardware design used to overcome the technical issues in thin-film research.
\end{abstract}

Keywords: solid-state NMR spectroscopy; magic angle spinning (MAS); thin films; solvent-matrix interactions; sensitivity boosting; polarization enhancement

\section{Introduction}

Thin films have a massive impact on the modern era of technology and have gained unprecedented interest during the past years due to their versatile properties and potential applications [1-5]. They are regarded as the backbone for advanced applications in various fields, such as optical devices [6], electronic devices [7], biosensors and plasmonic devices [8-10], environmental [11] and biological applications [12], solar cells [13-15], batteries [16-18] and so on. This class of advanced materials is generally defined as a thin layer of material having a thickness that ranges from fractions of a nanometer (i.e., monolayer) to several micrometers $[19,20]$. Thin films are composed of two parts: a layer or multilayer and a substrate where films are deposited on. These layers are extremely diverse, spanning from inorganic to organic materials, and are produced by two deposition methods: (1) physical methods and (2) chemical methods. The quality of thin films produced strongly hinges on their morphology and stability, which determines their final applications. It is also important to mention that the morphology and stability of thin films are strongly dictated by the deposition technique used for their preparation. Among the most commonly used physical deposition methods to prepare thin films are evaporation and sputtering techniques [21,22]. The general mechanism of the evaporation technique relies on changing the phase from solid to vapor and then again to solid phase on a specific substrate. This process usually takes place under vacuum or at controlled atmospheric conditions. Thermal vacuum evaporation is the simplest technique to form thin amorphous films, such as chalcogenide films [23,24], which are widely utilized in memory-switching applications [25,26], phase change materials [27,28] and solar applications [29]. Other evaporation techniques that are also sometimes used include electron beam evaporation [30-32] 
and laser beam evaporation $[33,34]$. On the other hand, sputtering is most commonly used to deposit metal and oxide films with careful control over crystalline structure and surface roughness $[35,36]$. In the sputtering process, an evacuated chamber composed of a metallic anode and cathode is used to generate a glow discharge, which results in the bombardment of ions [35]. The applied voltage during this process is usually in the order of several $\mathrm{keV}$, and a pressure of more than $0.01 \mathrm{mbar}$ is enough to ensure film deposition [35]. There are two common types of sputtering: (a) direct current (DC) sputtering and (b) radio frequency (RF) sputtering [37,38]. Aluminum nitride films are typical examples of films produced by sputtering $[37,38]$.

Even though physical deposition methods provide high-quality thin films, they require expensive equipment and are highly costly $[19,20]$. Hence, chemical deposition methods are sought as economically viable and widely used global methods for the production of thin films $[19,20]$. Chemical deposition depends on the chemistry of solutions, $\mathrm{pH}$, viscosity and so on. Among the paramount techniques used in chemical deposition is the sol-gel [39-41] route, which produces high-quality films with low equipment requirements. Additionally, this process produces a large quantity of nanosized films with modeled and controlled particle size, morphology, orientation and crystal structure, as well as optimized physical and chemical properties [42]. The sol-gel method has been applied to synthesize metal oxides, where it simply relies on the conversion of a colloidal suspension "sol" into a viscous gel [42]. Additionally, among the other important chemical deposition techniques that have been widely applied are: chemical vapor deposition (CVD) [43-46], spin coating [47-49], dip coating [50,51], chemical bath deposition [52,53] and spray pyrolysis technique $[54,55]$.

In order to tailor the final properties of thin films in a targeted application and obtain information on their morphology, chemical and physical properties, there is a dire and urgent need to carefully characterize such films. Several characterization techniques in the past have been deployed to analyze thin films [56-58], but only minor attention was given to solid-state NMR with its wide range of techniques [59]. Over the last decades, solid-state NMR has developed from a low-resolution shadowed technique into an indispensable one for structural and dynamic determination of a wide range of solid and semi-solid systems. NMR is a physical phenomenon based on the perturbation of the nuclear spin located in a strong external magnetic field using a weak oscillating magnetic field, which intern responds by an electromagnetic signal that is detected and transformed into spectra. When the oscillation frequency matches the intrinsic frequency of the targeted nuclei, resonance occurs; hence, valuable chemical information can be determined. NMR phenomenon is summarized in three sequential steps:

- The alignment of the nuclear spins along the applied external magnetic field.

- The perturbation of this alignment using a weak oscillating magnetic field.

- The detection of the NMR signal (voltage induced in a detection coil).

The interactions between the active nuclear spins and the magnetic fields determine the line shape of the peaks, thus the overall broadness of the spectra. Therefore, different solid-state NMR techniques were developed, including newly designed pulse sequences, to suppress and eliminate the broadness in the spectra of solid materials [60].

The arising orientation-dependent nuclear magnetic interactions in immobilized solid states is from the restricted thermal motions and lack of rapid molecular tumbling. This insufficient mobility exposes different types of internuclear and orientation-dependent nuclear interactions that accommodate information on the local geometric and electronic structure. Solid-state NMR is capable of performing a variety of experiments on a wide range of nuclei to retrieve valuable information on the local geometric and electronic structure from the emerged orientation-dependent nuclear magnetic interactions. The range of nuclei solid-state NMR is capable of measuring is not limited to the conventional nuclei for organic materials typical ${ }^{1} \mathrm{H}$ [61-64] and ${ }^{13} \mathrm{C}$ [65-68] nuclei for organic thin films, but extends in inorganic thin films to cover a huge portion from the periodic table such as ${ }^{2} \mathrm{H}[69,70],{ }^{7,8} \mathrm{Li}[71-73],{ }^{11} \mathrm{~B}[74],{ }^{14,15} \mathrm{~N}[72,75],{ }^{17} \mathrm{O}[76],{ }^{19} \mathrm{~F}[77-79]$, ${ }^{27} \mathrm{Al}[80-83],{ }^{29} \mathrm{Si}[84-87],{ }^{31} \mathrm{P}[71,72,86,88,89],{ }^{55} \mathrm{Mn}$ [90-92], ${ }^{59} \mathrm{Co}$ [93-95], ${ }^{69,71} \mathrm{Ga}[75,96]$, 
${ }^{75} \mathrm{As}[97],{ }^{89} \mathrm{Y}[98],{ }^{129} \mathrm{Xe}[99,100]$ and ${ }^{207} \mathrm{~Pb}[101]$. The most suitable solid-state NMR
techniques for different thin-film types are summarized below in Table 1.

Table 1. A summary of the most suitable solid-state NMR techniques for the chemically different thin-film types. MAS: magic angle spinning; DNP: dynamic nuclear polarization; MRFM: magnetic resonance force microscopy.

\begin{tabular}{cccc}
\hline NMR Active Nuclei & Chemical Connectivity & Solid State NMR Technique & References \\
\hline${ }^{1} \mathrm{H}$ & Organic/Inorganic & 1D, 2D MAS and multiple & {$[61-64]$} \\
${ }^{2} \mathrm{H}$ & Organic & quantum & {$[69,70]$} \\
${ }^{7,8} \mathrm{Li}$ & Inorganic & 1D, 2D MAS & {$[71-73]$} \\
${ }^{11} \mathrm{~B}$ & Inorganic & 1D MAS and $\beta-\mathrm{N}$ R & {$[74]$} \\
${ }^{13} \mathrm{C}$ & Organic & 1D, 2D MAS & {$[65-68]$} \\
${ }^{14,15} \mathrm{~N}$ & Inorganic & High-field NMR & {$[72,75]$} \\
${ }^{17} \mathrm{O}$ & Inorganic & fast MAS, isotopic enrichment & {$[76]$} \\
${ }^{19} \mathrm{~F}$ & Organic/Inorganic & 1D MAS, MRFM & {$[77-79]$} \\
${ }^{27} \mathrm{Al}$ & Inorganic & $1 \mathrm{D}, 2 \mathrm{D}$ MAS, high-field NMR & {$[80-83]$} \\
${ }^{29} \mathrm{Si}$ & Organic/Inorganic & 1D MAS & {$[84-87]$} \\
${ }^{31} \mathrm{P}$ & Organic/Inorganic & 1D, 2D MAS, DNP & {$[71,72,86,88,89]$} \\
${ }^{55} \mathrm{Mn}$ & Inorganic & NMR relaxometry & {$[90-92]$} \\
${ }^{59} \mathrm{Co}$ & Inorganic & NMR relaxometry & {$[93-95]$} \\
${ }^{69,71} \mathrm{Ga}$ & Inorganic & High-field NMR & {$[75,96]$} \\
${ }^{75} \mathrm{As}$ & Inorganic & 1D MAS & {$[97]$} \\
${ }^{89} \mathrm{Y}$ & Inorganic & 1D MAS & {$[98]$} \\
${ }^{129} \mathrm{Xe}$ & Inorganic & Hyper-polarization & {$[99,100]$} \\
${ }^{207} \mathrm{Pd}$ & Fast MAS, DNP & {$[101]$} \\
\hline
\end{tabular}

\section{Chemical Connectivity}

\subsection{Inorganic Films}

Carbon-based thin films [102] are involved in a wide range of applications starting from porous carbon/graphene nanosheets $[103,104]$ in high-performance supercapacitors to diamond films [105], showing superconductive properties when doped with boron. The superconductive properties of diamond films doped with boron open the route for the exploration of the superconductivity origin in the proximity of metal-insulator transition. Therefore, four types of boron-doped diamond films having different crystallization properties and thickness (i.e., thick-100, thin-100, 111 and polycrystalline) were deposited on substrates by means of microwave plasma-assisted chemical vapor deposition method and investigated using ${ }^{11} \mathrm{~B}$ NMR [74].

${ }^{11} \mathrm{~B}$ is usually the nuclide choice in NMR since it is more sensitive and yields a sharper signal compared to the other boron nuclei, but when boron is doped in the diamond film, the signal intensity is directly affected by the amount of doped boron. Therefore, ${ }^{11} \mathrm{~B}$ is the measured nuclei unless the sample is enriched with ${ }^{10} \mathrm{~B}$. Figure 1 shows a ${ }^{11} \mathrm{~B}$ NMR spectrum at $4.2 \mathrm{~K}$ and $34.887 \mathrm{MHz}$ for the (111) diamond film [74]. The spectrum consists of 2 overlapped peaks for different boron-doped sites in the diamond films, a narrow peak located around $\Delta f=0$ with a linewidth of $5 \mathrm{kHz}$ and a broad one extended between $\Delta f=-40$ and $20 \mathrm{kHz}$. The narrow peak (blue shade) was assigned for high symmetry boron sites placed in substitutional positions of the carbon ones, and the broader peak (green shade) was assigned for boron sites in lower local symmetry, including boron-hydrogen complexes, interstitial boron sites, boron-boron occupied sites and boron sites located near lattice defects. Boron-hydrogen complexes are considered the dominant species in the broad peak (green shade) due to the synthetic process utilized, which includes using a mixed gas of $\mathrm{CH}_{4},\left(\mathrm{CH}_{3}\right)_{3} \mathrm{~B}$ and $\mathrm{H}_{2}$. 


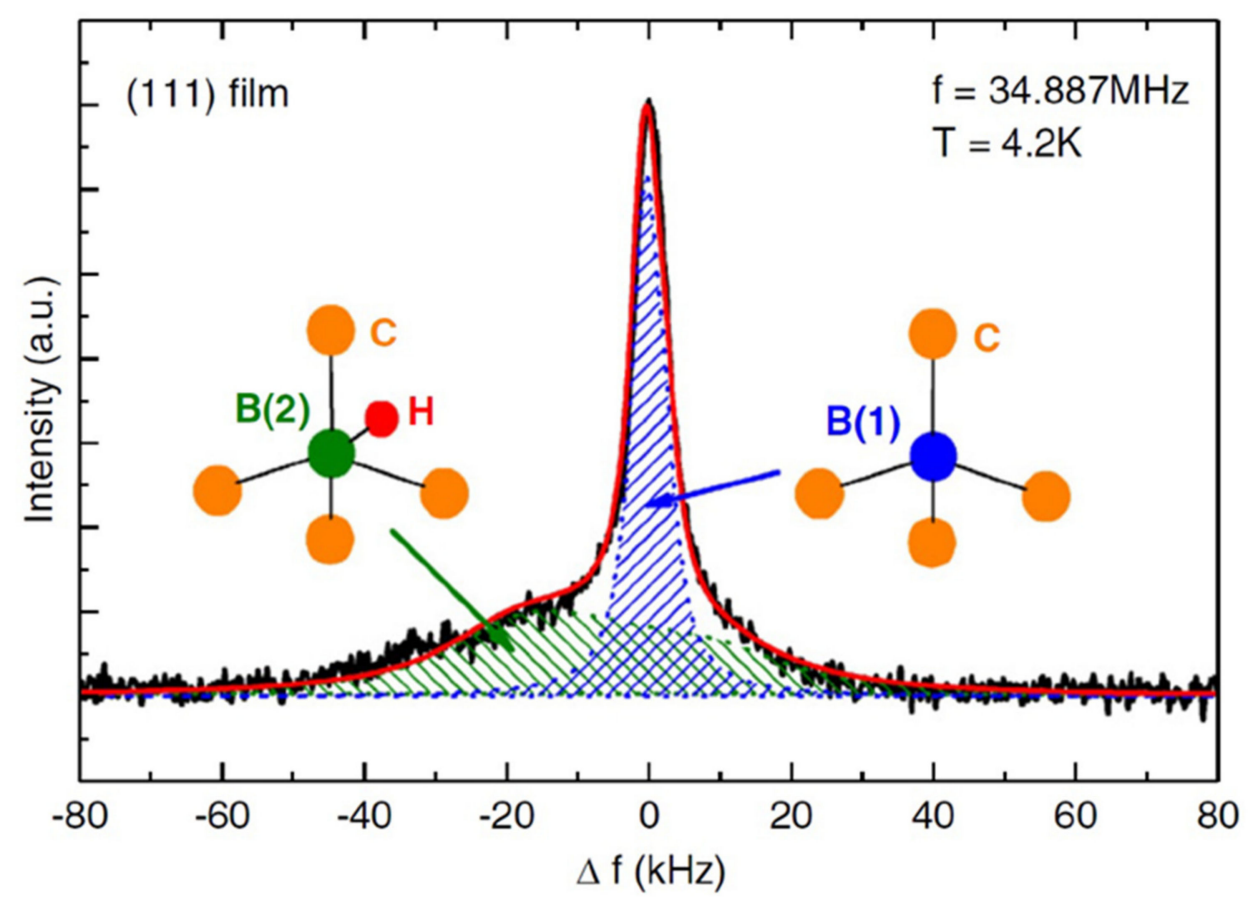

Figure 1. ${ }^{11} \mathrm{~B}$ NMR spectrum for the (111) film, the fitted red curve shows 2 boron sites, which are identified as $\mathrm{B}(1)$ blue and $\mathrm{B}(2)$ green, respectively. Reproduced with permission [73]. Copyright 2006, Taylor \& Francis. www.tandfonline.com. (accessed on April 2021).

Moreover, it is worthwhile to pinpoint that resolving the solid-solid interface on an atomic scale is a major obstacle facing different fields of material sciences. Complex oxide heterostructures are a combination of two or more different phases where the solid-solid interface enhances the functional properties. Preparing complex oxide heterostructure as thin films and, in particular, as vertically aligned nanocomposite films have promising applications in different fields, including superconductors and data storage media. In contrast to the conventional planar multi-layered heterostructures, the interfaces are aligned perpendicular to the layout of the substrate. A deep analysis of the interfacial surface is required for better understanding and optimizing the thin film designs [76].

${ }^{17} \mathrm{O} \mathrm{NMR}$ is a valuable technique for studying the presence of motion and the local structural distortions caused mainly by defects over the interface in heterostructures [106]. However, acquiring useful information from ${ }^{17} \mathrm{O}$ NMR requires the isotopic enrichment of ${ }^{17} \mathrm{O}$ nuclei, which is done mainly by labeled ${ }^{17} \mathrm{O}_{2}$ gas state or $\mathrm{H}_{2}{ }^{17} \mathrm{O}$ in an aqueous state [107]. Figure 2a shows the ${ }^{17} \mathrm{O} \mathrm{NMR}$ spectrum of the $\mathrm{CeO}_{2}-\mathrm{SrTiO}_{3}$ vertically aligned nanocomposite lift-off thin films, enriched with ${ }^{17} \mathrm{O}$ at $450{ }^{\circ} \mathrm{C}$ and spun at $50 \mathrm{kHz}$ in a $1.3 \mathrm{~mm}$ rotor [76]. From the deconvolution of the obtained ${ }^{17} \mathrm{O}$ spectrum, the $\mathrm{CeO}_{2}$ signal observed at 879 ppm shows several components overlapped, including a narrow peak at 877 ppm for bulk $\mathrm{CeO}_{2}$ located near the core of the nanopillars and a broad $\mathrm{CeO}_{2}$ environment closer to the interface. Furthermore, upon analyzing the $\mathrm{CeO}_{2}$ signal in terms of symmetry, the signal appears to be asymmetric, and additional peaks are detected at 837 and 1000 ppm corresponding to the $\mathrm{CeO}_{2}$-like interfacial environment. Additional to the $\mathrm{CeO}_{2}$ environment, $\mathrm{SrTiO}_{3}$ and $\mathrm{ZrO}_{2}$ (from NMR rotor) signals appear at 466 and 377 ppm, respectively. Between the $\mathrm{CeO}_{2}$ and $\mathrm{SrTiO}_{3}$ environments, a broad resonance centered between the different environments appears clearly at $680 \mathrm{ppm}$ and another at a smaller one at 575 ppm ascribed to $\mathrm{SrTiO}_{3}$ interfacial environment. Figure 2b, c shows isotropic chemical shifts as a function of distance from the interface for several predicted interfacial structures using DFT calculations. Figure $2 \mathrm{~b}$ shows nine DFT calculated lowest energy $0^{\circ}$ interfaces (A-I), where the layer linked to the $\mathrm{CeO}_{2}$ side shows a wide spread of values centered close to the bulk $\mathrm{CeO}_{2}$ side around $820 \mathrm{ppm}$ and some other environments predicted at different frequencies at around 560 and 1000 ppm, which arise from the layer on the $\mathrm{SrTiO}_{3}$ and 
three-fold coordinated $\mathrm{CeO}_{2}$. Inversely to the formal interface, Figure $2 \mathrm{c}$ shows the $45^{\circ}$ interfaces where the missing $680 \mathrm{ppm}$ signal in the $0^{\circ}$ interfaces appears and corresponds to the shared anionic layer. Further calculations show the presence of two interfaces forming the signal at $680 \mathrm{ppm}$ where the first corresponds to the anion layer arranged according to the $\mathrm{SrTiO}_{3}$ structure with $14 \mathrm{O}^{2-}$ ions and the second according to the $\mathrm{CeO}_{2}$ structure with $20 \mathrm{O}^{2-}$ ions. From the calculated shifts the interfacial oxygen's intermediate between the $\mathrm{CeO}_{2}$ and $\mathrm{SrTiO}_{3}$ structures, some modifications appear on the local oxygen environment adjacent to the $\mathrm{SrTiO}_{3}$ interface as fewer oxygen ions are available to coordinate with all the $\mathrm{Ce}^{4+}$ ions, leading to the withdrawal of more electron density from the adjacent oxygen ones, thus deshielding them and perturbing the chemical shift. On the other hand, the $20 \mathrm{O}^{2-}$ ion $\mathrm{CeO}_{2}$ interface shows a predicted range of 660-700 ppm consistent with the experimental results at $680 \mathrm{ppm}$, thus showing tetrahedrally coordinated oxygen ions adjacent to two $\mathrm{Ce}^{4+}$ ions and one $\mathrm{Ti}^{4+}$ and $\mathrm{Sr}^{4+}$ ions [76].

\subsection{Organic Films}

Organic semiconducting thin films have promising applications in different industrial fields, such as organic light-emitting diodes [108], organic solar cells [109] and organic thin-film transistors [110]. For obtaining the highest performance of a film-based device, the molecular orientation of the organic thin films should be studied. Solid-state NMR, contrary to X-ray diffraction, is capable of extracting structural information and molecular orientation from amorphous compounds, but the amount of information that could be extracted is limited to the sensitivity of hardware and nuclei. Therefore, in order to obtain the desired sensitivity, the maximum amount of sample should be packed in a bulk form, or polarization enhancement techniques should be used in the case of thin films. Static dynamic nuclear polarization (DNP) enhanced solid-state NMR was chosen to enhance the sensitivity of phenyldi(pyren-1-yl) phosphine oxide (POPy $)$, a semiconducting organic material frequently used in organic light-emitting diodes for its electron transport properties. In the selected DNP experiments, a microwave irradiates dispersed radicals in the sample, which leads to an electron polarization transfer from the polarized electrons towards the ${ }^{1} \mathrm{H}$ population in the sample. This polarization is further transferred into other nuclei by means of cross-polarization $(C P)$, resulting in the sensitivity enhancement for the ${ }^{31} \mathrm{P}$ nuclei in these samples [111].

Amorphous $\mathrm{POPy}_{2}$ thin layers were deposited on $\left(\mathrm{SiO}_{2}\right.$ or polytetrafluoroethylene) substrates using vacuum-deposited and drop-cast techniques. The thin layers were doped with a polarizing agent (bisnitroxide radical), and the concentration of radicals $(0.25 \mathrm{wt} \%)$ was chosen to avoid electron-electron exchange couplings, which decrease the DNP efficiency. ${ }^{31}$ P CP DNP solid-state NMR experiments under static conditions were performed on perpendicularly aligned $\mathrm{POPy}_{2}$ thin layers with respect to the external magnetic field to obtain conformational information on ${ }^{31} \mathrm{P}=\mathrm{O}$ from the chemical shift anisotropy (CSA). Figure 3 shows the ${ }^{31} \mathrm{P}$ CSA spectra for amorphous $\mathrm{POPy}_{2}$ thin layers deposited on glass substrates in the presence and absence of DNP enhancement [111]. Additional to the presence and absence of DNP enhancement, different layer deposition techniques were compared in Figure 3a,b and a different number of sheets were compared, leading to the calculation of the DNP enhancement factor according to the integral signal intensity of the CSA in the presence and absence of DNP enhancement in Figure 3a,c. The DNP enhancement factor was affected by several factors, including the type of substrate and the number of sheets used, where using only one $\mathrm{POPy}_{2}$ thin layer gave the highest enhancement, which could be attributed to the cooling efficiency of the thin film. The CSA patterns for both samples were axially symmetric and covered a wide range of the chemical shift $(-100$ to $100 \mathrm{ppm}$ ) depending on the $\mathrm{P}=\mathrm{O}$ orientation. $\mathrm{P}=\mathrm{O}$ axis of $\mathrm{POP}_{2}$ having an orientation parallel to the external magnetic field is around $-100 \mathrm{ppm}$, while the perpendicular orientation is around $100 \mathrm{ppm}$. The CSA pattern of the vacuum deposited $\mathrm{POPy}_{2}$ shows a higher intensity around $100 \mathrm{ppm}$ compared to that of the drop cast sample, and this indicates 
a greater contribution for the parallel aligned $\mathrm{P}=\mathrm{O}$ orientation in the vacuum-deposited $\mathrm{POPy}_{2}$ film [111].

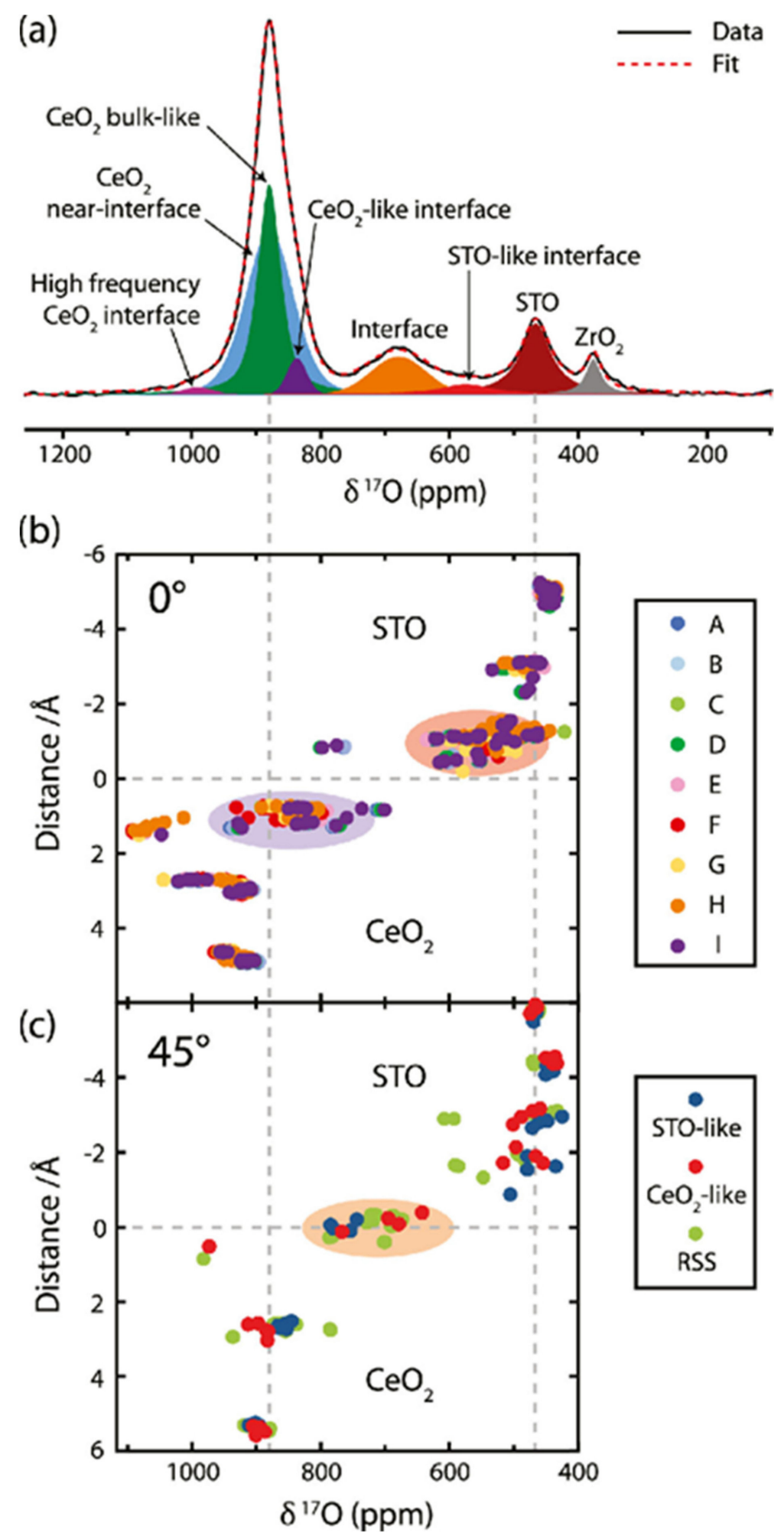

Figure 2. (a) ${ }^{17} \mathrm{O} \mathrm{NMR}$ spectrum for $\mathrm{CeO}_{2}-\mathrm{SrTiO}_{3}$ nanopillar lift-off isotopically enriched films. $(\mathbf{b}, \mathbf{c})$ DFT-calculated isotopic chemical shifts as a function of distance from the interface of different interfacial structures. Three structure interfaces of the simple model and a low-energy structure were found from random structure searching in $0^{\circ}$ interface (b) and $45^{\circ}$ interface (c). Reproduced with permission. [76] Copyright 2020, American Chemical Society. 


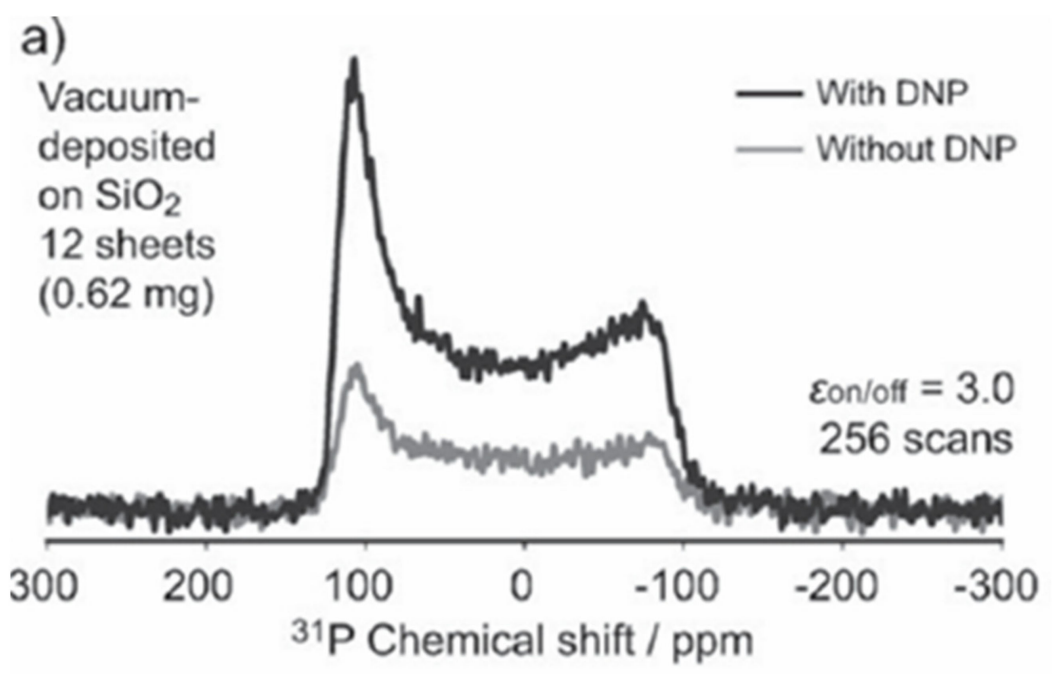

b)

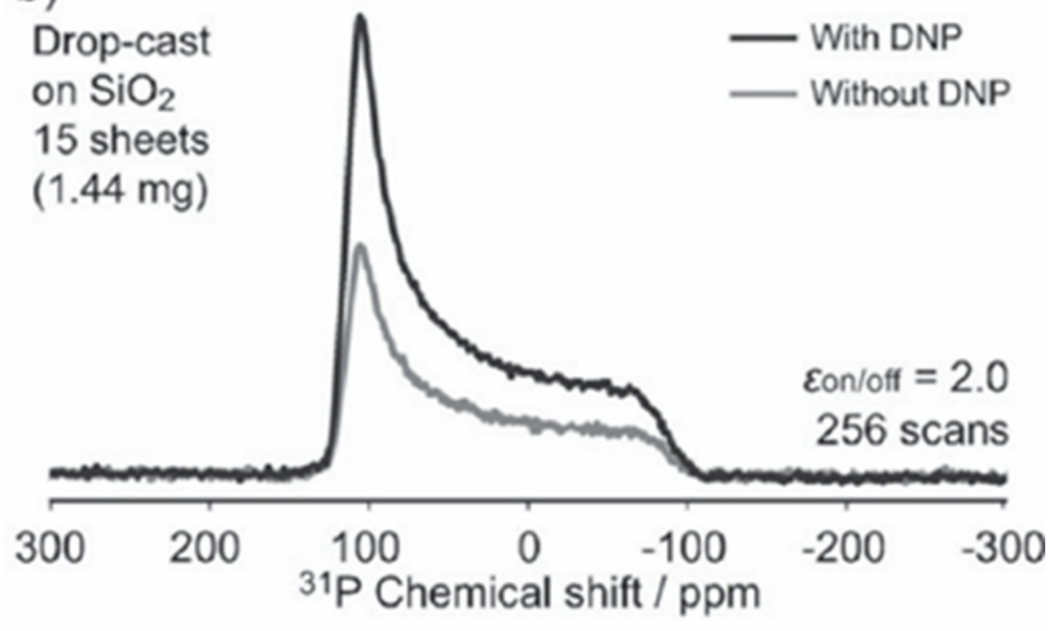

c)

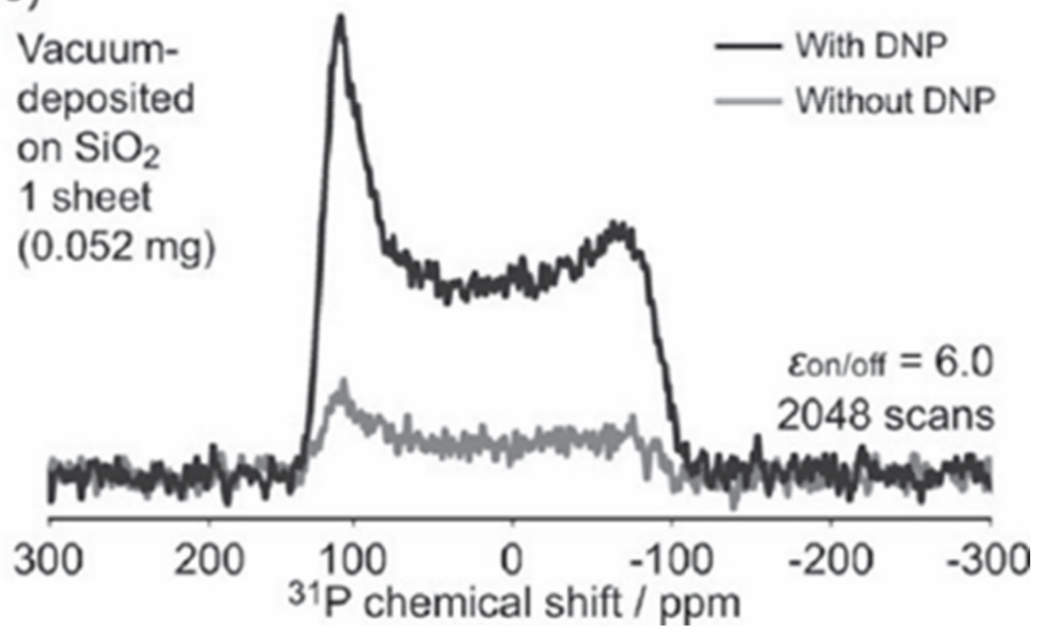

Figure 3. ${ }^{31} \mathrm{P}$ CSA NMR spectra for POPy 2 film with (black) and without (gray) DNP enhancement: (a) vacuum-deposited on $\mathrm{SiO}_{2}$ (12 sheets), (b) drop-cast on $\mathrm{SiO}_{2}$ (15 sheets) and (c) vacuum-deposited on $\mathrm{SiO}_{2}$ (1 sheets). Reproduced with permission. [111] Copyright 2017, Angewandte Chemie, Wiley-VCH. 
Conjugated polymers offer significant advantages over different materials when used in printable and flexible semiconductors due to their cheap, sustainable and solutionprocessable properties. The high mobility in these materials comes from the partial electron charge transfer between the donor and acceptor groups, which depends on the chemical properties for these groups, such as the polymeric backbone conformations and molecular level stacking arrangement of the adjacent polymer chains. However, challenges face the development of these materials in both their bulk and thin film forms since few characterization techniques are able to probe the atomic level in the presence of disorder and provide structural, conformational and packing information. Therefore, solid-state NMR with its MAS and DNP techniques offer the ability to characterize the polymeric backbone conformations and packing arrangement for the high-mobility donor-acceptor copolymer diketopyrrolo-pyrrole-dithienylthieno[3,2-b] thiophene (DPP-DTT) [112].

Figure 4 shows the DNP enhanced ${ }^{13} \mathrm{C} C P$ MAS NMR spectra for (a) 1D spectra for bulk DPP-DTT polymer with and without microwave irradiation at $263 \mathrm{GHz}$, where the enhancement factor reached 130 for the aliphatic part of the polymer [112]. The spectrum shows low resolution that is demonstrated in broader linewidths due to the presence of a paramagnetic polarizing agent on one side and the reduction of thermal motional averaging since the experiment is performed at $100 \mathrm{~K}$ on the other side. The $2 \mathrm{D}^{1} \mathrm{H}_{-}{ }^{13} \mathrm{C}$ HETCOR spectra for the DPP-DTT polymer in its bulk and thin film form using the drop-cast technique are shown in Figure 4b,c. Comparing the 2D HETCOR spectra shows that the structure in both bulk and film forms are highly identical, this is determined based on the detected weak intermolecular interactions between the quaternary carbons $\mathrm{C} 1$ and $\mathrm{C} 2$, and the corresponding hydrogens $\mathrm{H} 6 / \mathrm{H} 9$ showing that the expected structure (based on the simulation model) is preserved even after applying the solution deposition technique. 1D spectra for DPP-DTT polymer in its thin-film form using the drop-cast and spin-coating technique are shown in Figure 4d. It is worth mentioning that the DNP experiments provide high-quality spectra in a relatively short experimental time (hours scale), despite using a limited amount of sample $(1 \mathrm{mg}) .{ }^{13} \mathrm{C}$ NMR spectroscopy is not expected to provide useful information on drop-cast and spin-coated films at natural abundance for such limited sample amounts (1 mg) without using the DNP technique [112].

Combining several techniques for collecting structural information about DPP-DTT films provides a great overview of its high-charge carrier mobility ion devices. Two of the most important factors contributing to the efficiency of intramolecular charge transport are the degree of backbone planarity, which is based on the torsion energies of the backbone groups, and the hydrogen bonding located between thiophene and DPP units [112].

The membrane technology has emerged with conventional separation methods, which are well known and used in industry due to their sustainable production process, simplified scaling-up and energy cost efficiency [113]. There has been a tremendous amount of time and effort devoted to design novel membrane materials that are capable of fast and efficient separation. The three aforementioned benefits were achieved with the development of thinfilm composite membranes, especially when synthesized from sustainable sources [114]. Those materials designed from an ultra-thin selective layer supported on a porous polymer template, and their applications have ranged from ionic filtration, metal cation separation and gas permeability $[115,116]$. 
a

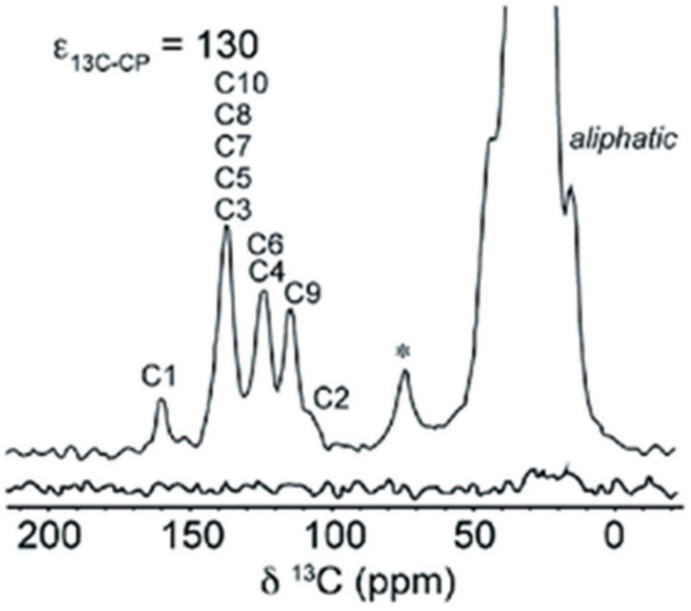

b

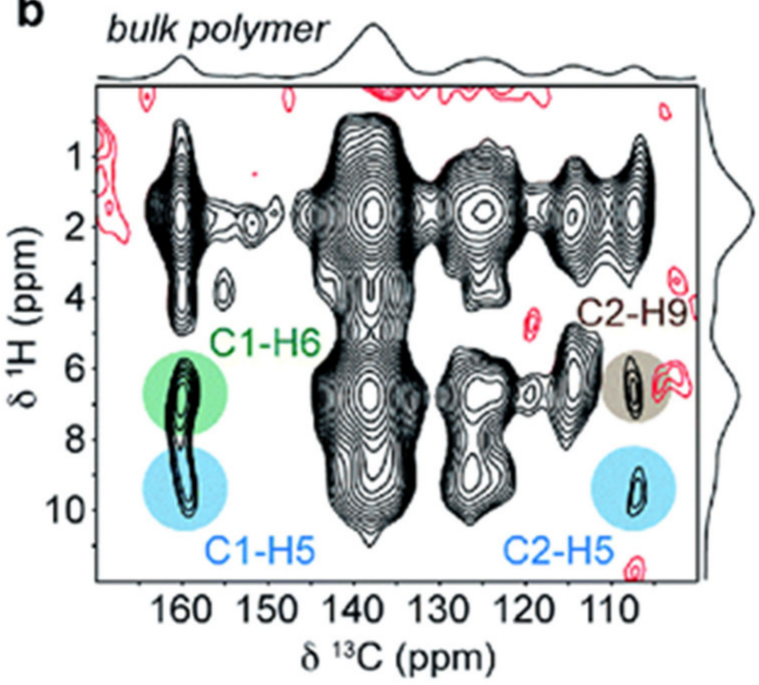

d
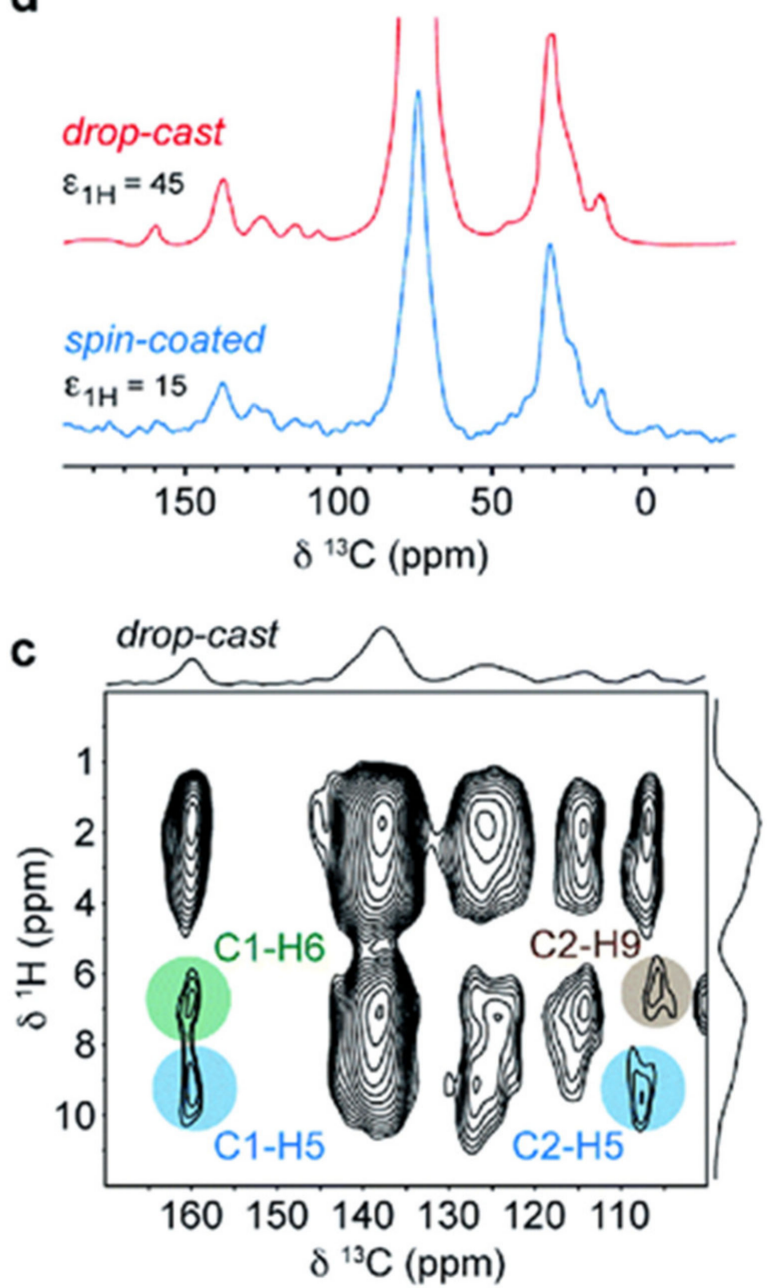

Figure 4. (a) ${ }^{13} \mathrm{C}$ DNP-CPMAS NMR spectra for DPP-DTT bulk polymer with (upper spectrum) and without (lower spectrum) DNP enhancement. (b) ${ }^{1} \mathrm{H}-{ }^{13} \mathrm{C}$ DNP-HETCOR NMR spectra for DPP-DTT bulk polymer. (c) ${ }^{1} \mathrm{H}-{ }^{13} \mathrm{C}$ DNPHETCOR NMR spectra for the drop-cast film. (d) ${ }^{13} \mathrm{C}$ DNP-CPMAS NMR spectra for DPP-DTT drop-cast (red) and spin-coated (blue) films. Reproduced with permission. [112] Copyright 2017, The Royal Society of Chemistry.

\section{Recent Advancement in NMR Strategies and Hardware Design}

\subsection{Hardware Advancements (Probe and Coil Design)}

Magic angle spinning (MAS) is one of the most essential and valuable techniques in solid-state NMR $[117,118]$ since it provides high-resolution spectra not only for crystalline samples but also for amorphous ones. The high resolution is obtained upon mechanically rotating the sample over an axis aligned at the magic angle $\left(54.7^{\circ}\right)$ to the external magnetic field. Among the few thin-film samples measured by MAS NMR, all sample preparation methods used were based on scratching the sample off the substrate previous to the rotor packing $[81,84,85,119,120]$, lift-off technique, which is mainly composed of the water-soluble buffer layer method [121], followed by the polymer transfer layer method [122] and stacking the rotor with proper size pieces of thin films [123]. Solid-state NMR measurements on thin films were only possible in static mode (without sample rotation); thus, high-resolution spectra were limited to samples without anisotropic interactions $[75,97]$. The non-destructive property of MAS NMR leads to the development of new probe and coil designs capable of measuring thin films, including the disk MAS design present in Figure 5 [124]. Inspired from the MAS design having a thin capillary tube fixed on top of the rotor [125-127], the disk MAS design requires the fixing of a circular quartz substrate glued to an attachment on top of a $4 \mathrm{~mm}$ pencil design rotor [124]. Additionally, 
an external probe composed of a silver-wire coil, chip capacitors and trimmer capacitors was assembled and secured to the spinning module. Radio frequency (RF) amplitude and inhomogeneity calibration were performed on the disk MAS, and the radio frequency efficiency was 2.0 folds lower compared to that of the conventional MAS probe. The significant advantages of the disk MAS are summarized in its ability to characterize the thin film under the nondestructive MAS conditions and tracing the identical thin film undergoing ex situ experiments, such as annealing, discharging/charging and degradation [124].

(a)

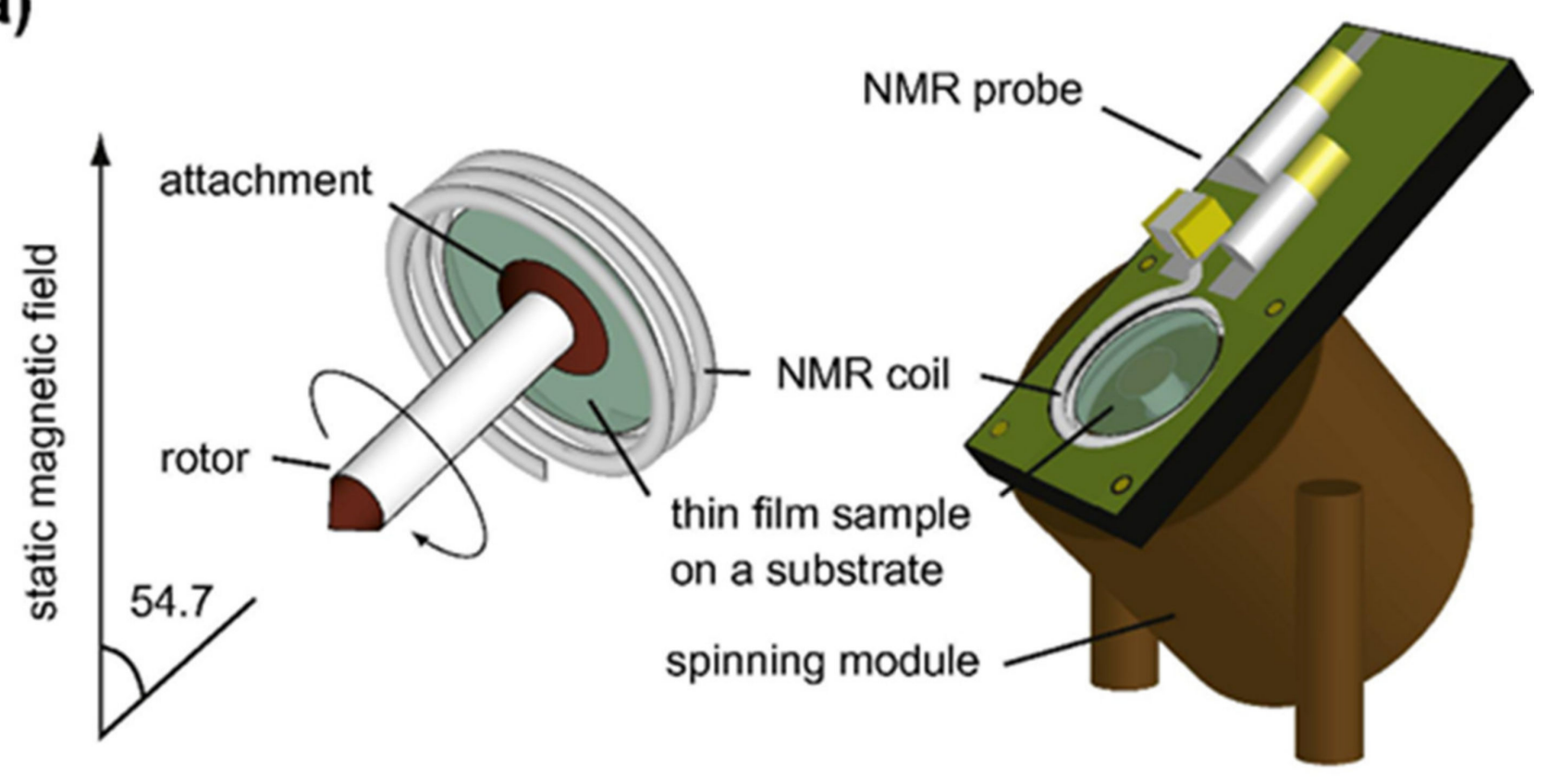

(b)

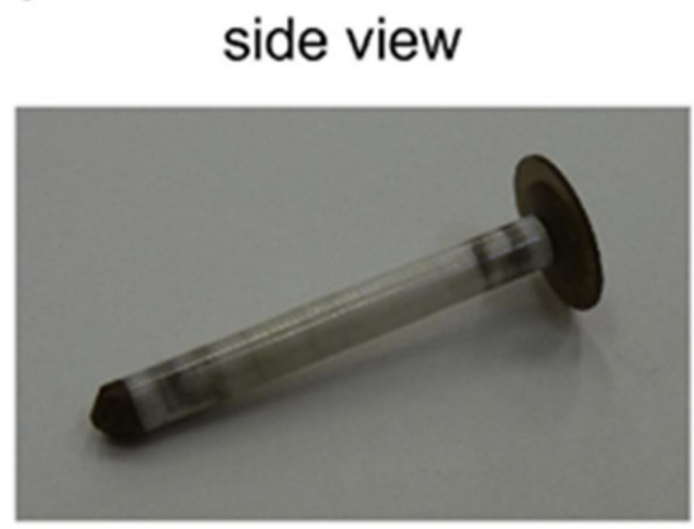

\section{front view}

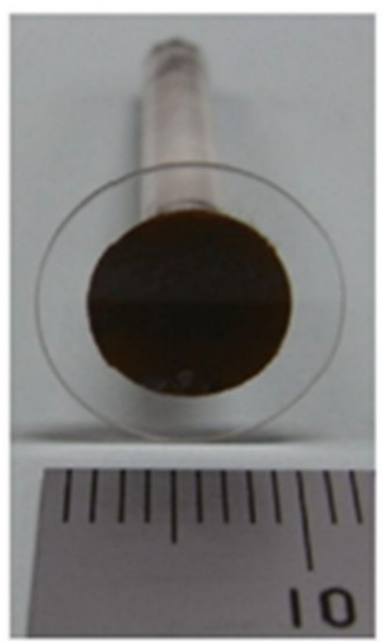

(c)

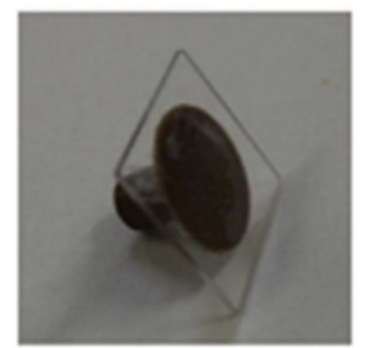

Figure 5. (a) A schematic description for the disk MAS design, including its fit in the NMR probe (b) a side and front view of a $4 \mathrm{~mm}$ pencil type rotor (Agilent technology, Inc.) with an attached $12 \mathrm{~mm}$ quartz disk, and (c) a photograph of the square quartz substrate. Reproduced with permission. [124] Copyright 2011, Elsevier. 
Several groups were able to produce microcoils using lithographic methods, but despite all the efforts conducted, these approaches did not reach the mainstream production in NMR spectroscopy [128-130]. Several microcoil designs were introduced and tested previously, including the micro helix coil, planar micro helix coil, saddle coil, stripline design [131] and the microslot design [132]. The latter design has a comparable approach with the stripline one, which, in turn, alternates from the helical coil design. Planar helices microcoil designs suffer from several problems, including B1 field homogeneity, increase in RF shielding currents and windings of the microcoil, thus leading to a severe reduction in resolution and sensitivity and difficulty in implementing 2D NMR methods [133].

The passage of an RF current through a straight wire leads to the generation of an electromagnetic RF field encircling the wire. When the wire is in a position parallel to a static magnetic field, a new magnetic field is generated perpendicular to the static one, which can be used for the excitation of NMR spins. The homogeneity of the static magnetic field is barely disrupted from the positioned wire. The stripeline coil is basically a 2D flat copper wire covered with symmetric ground planes from both sides to confine the $\mathrm{RF}$ radiation, reduce the RF field strength decay and keep it homogeneous. The applied RF current passes through the flat strip, and a generated RF field encircles the strip. The local current density is at maximum in the middle of the strip, particularly between the boundaries of the restriction, which results in a high RF field at the sample placed along the channel. The signal generated from the sample dominates the overall signal detected by the coil. Several factors were found to be affecting the resolution and sensitivity of the stripline coil, including the tapering angle, gap width and the aqueous fluid filling the gap, as shown in Figure 6 [134]. Compromised parameters were chosen depending on numerical simulation to obtain the highest resolution and sensitivity [133-135]. The novel stripline probe technology proved to be valuable in studying thin films where it provided high sensitivity to detect highly mobile hydrogen species in photochromic thin films [98].

\subsection{Sensitivity Detection (MRFM, $\beta$-Magnet)}

NMR has established its position as an inevitable analytical technique in many areas of research, but every technique has its limitations and sensitivity, which is the main issue for NMR. NMR spectroscopy has suffered from relativity low sensitivity, especially in detection methods due to the extremely low thermodynamic population difference between the nuclear spin levels. Different methods for improving the detection sensitivity of NMR have been developed based on mechanical detection, where the first successful application was called Magnetic Resonance Force Microscopy (MRFM) [136]. The basic principle of MRFM relies on the use of a mechanical cantilever already known from Atomic Force Microscopy to detect exerted forces on a spin system in the presence of an inhomogeneous magnetic field [137]. The force experienced by the nuclear magnetic dipole moment upon settling in an external gradient field is detected by the atomic force microscope cantilever by mechanical means, and thus sub-angstrom resolution may be reached from the cantilever deflection. The inhomogeneous magnetic field is created by introducing a small magnetic particle in an external magnetic field, which results in the variation of the Larmor resonance over the sample; thus, particular slices of the sample can be excited through the variation of the irradiation frequency or the position of the magnetic field gradient source. The configuration for MRFM is illustrated in Figure 7 [77].

The driving force for developing the MRFM was the possibility to detect a single spin, which could make it an important tool in quantum computation, the efforts were successful [138], and MRFM was developed not only to detect electrons [139] but also protons [140] and latter isotope selective nuclei in organic monolayers [141]. The advancements in MRFM continued with the advanced observation of magnetization, enhanced resolution and no gradient (BOOMERANG) technique [142], ending with the coupling of ultrasensitive MRFM with 3D image reconstruction to achieve magnetic resonance imaging with $<10 \mathrm{~nm}$ resolution limit [143]. 


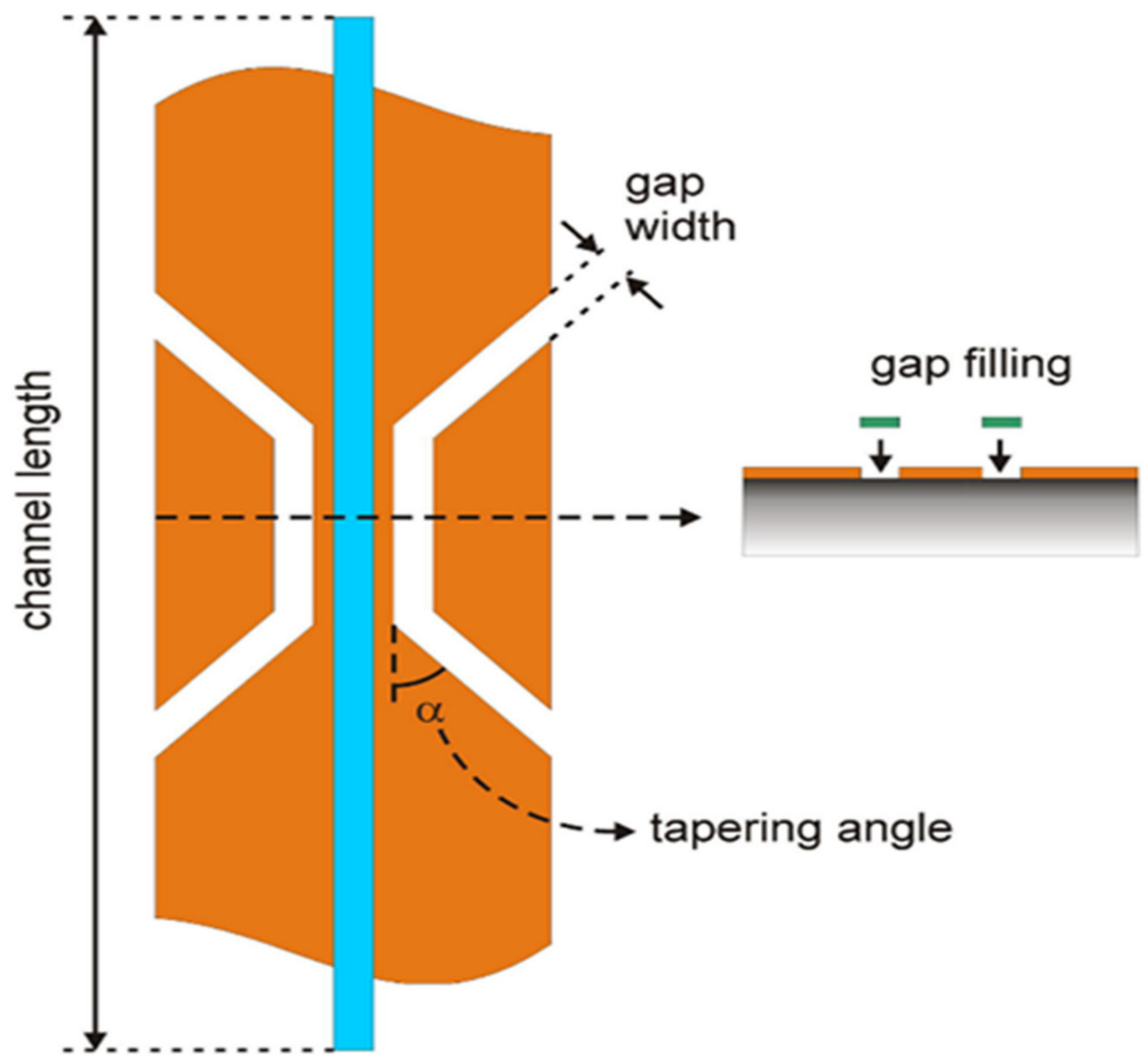

Figure 6. Parameters that are varied for optimization of the resolution. Reproduced with permission. [134] Copyright 2009, Elsevier.

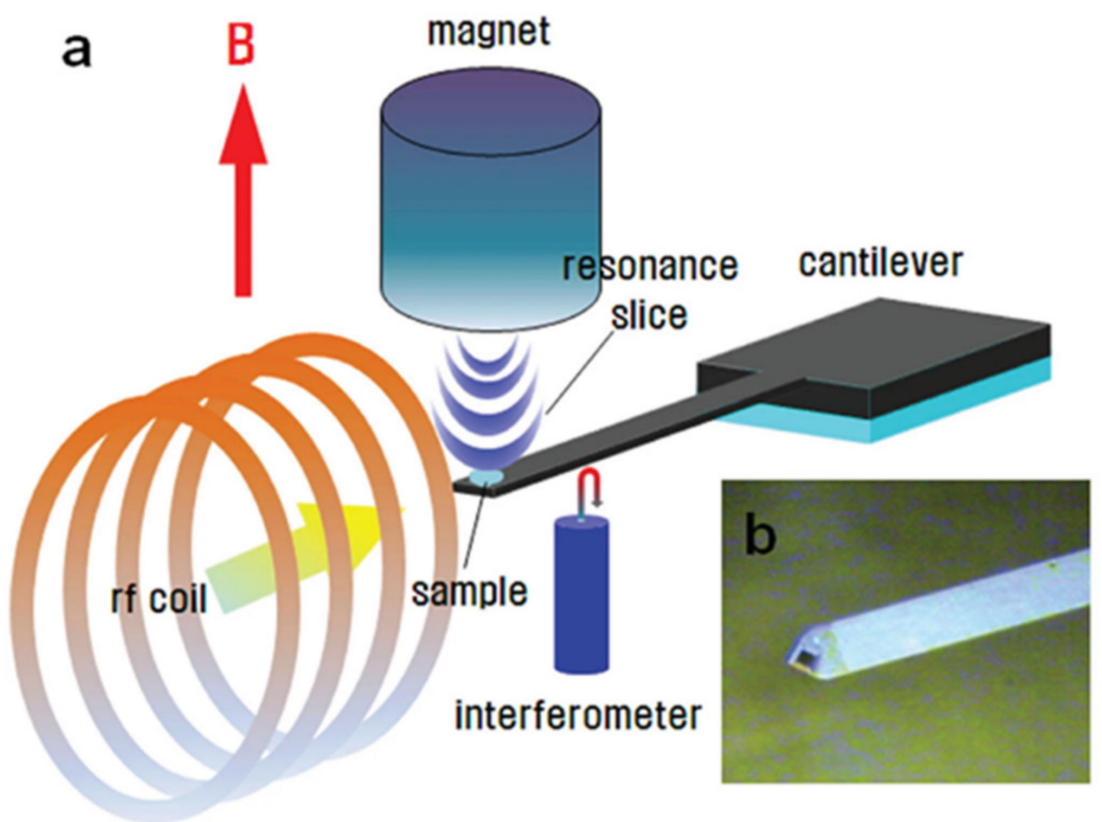

Figure 7. (a) A schematic description of the MRFM setup and (b) showing the original cantilever tip where the sample is deposited (appearing dark). Reproduced with permission. [77] Copyright 2013, Nature. 
Although advanced solid-state NMR techniques and pulse sequences, including MAS, are not applicable in MRFM, an NMR approach based on force detection method for chemical investigations using relaxation times or chemical shifts was developed [77]. Quadrupole nuclei and low $\gamma$ nuclei are the best candidates for high-resolution imaging since the external field gradient does not have a major sensitivity enhancement effect, thus leaving this enhancement to be determined by the local structure experienced by the nuclei [144]. In particular, applications for MRFM includes the fields of coatings, colloids and semiconductors $[77,145]$.

The implantation of probes (radioactive ions) that are highly spin polarized is an effective technique to overcome the low number of nuclei for a measurable signal in nanoscopic systems [146]. Optical pumping is an advanced method for spin polarization, as it provides reproducible results even with a very high degree of spin polarization $(10-100 \%)$. Additionally, the need for extreme cooling of the ions is not compulsory in optical pumping since it depends on atom/ion interaction with circularly polarized laser beams. The transfer of polarization from the electron to the nucleus is completed via hyperpolarization interaction $[147,148]$.

$\beta$-NMR spectroscopy depends on the $\beta$ particles emitted anisotropically during the decay of spin-polarized nuclei. The configuration for $\beta$-NMR is illustrated in Figure 8 [149]. The beam exposed to optical pumping implants into the NMR sample after its passage through the polarization section. A continuous RF field is applied on the sample leading to the nuclear sub-level transitions at the resonance frequency, and the decrease in spin polarization as the change in $\beta$-decay asymmetry is recorded. The employment of a highly spin-polarized radioactive beam with $\beta$-NMR creates a novel nuclear method of detection that has enough sensitivity to detect the presence of a single probe nucleus and build up a typical spectrum [150]. Due to its novel features such as high magnetic fields and the ability to control the depth of implantation ranging between 2-200 nm, $\beta$-NMR found many applications in surface science [151], insulators [152], semiconductors [153,154], antiferromagnetics [155] and thin films [73,149,156-158].

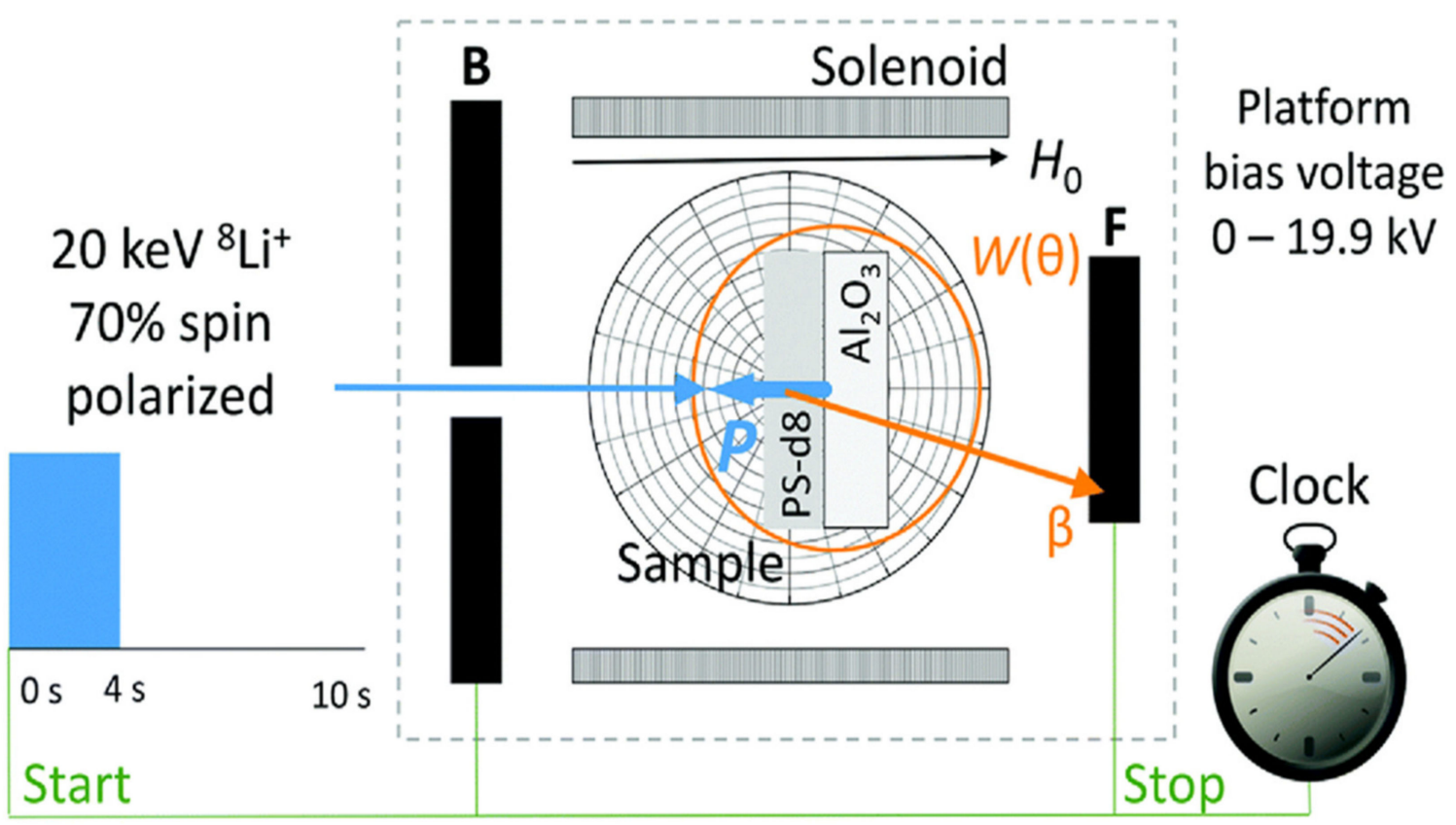

Figure 8. A schematic description of the $\beta$-NMR setup where the experiment starts with a $4 \mathrm{~s}$ long ${ }^{8} \mathrm{Li}^{+}$pulse, followed by the $\beta$ particles emitted anisotropically during the decay of spin-polarized nuclei. The $\beta$ trajectory (orange line) is shown hitting the detector. Reproduced with permission. [149] Copyright 2017, The Royal Society of Chemistry. 


\subsection{Polarization Enhancement (Natural Abundance DNP versus Thin Films)}

The transfer of polarization from electrons spins to nuclear ones through hyperfine interactions is called hyperpolarization. Upon the relaxation of the electron spin temperature back to the thermal equilibrium after its exposure to external microwaves, nuclear spins are hyperpolarized, leading to a drastic enhancement in the obtained NMR spectra. The term dynamic nuclear polarization (DNP) was assigned to distinguish this scheme from alternative hyperpolarization methods [159].

DNP NMR spectroscopy has been successfully applied to materials research more than to other biological systems due to the fact that the experiments are conducted at cryogenic temperatures between $20 \mathrm{~K}$ and $110 \mathrm{~K}$. At these cryogenic temperatures, maximum sensitivity enhancements are obtained since electron relaxation time is long enough for the polarization to be transferred to the nuclei. In the case of an ideal nuclear polarization transfer, the NMR signal could match the ESR one, and DNP NMR could find new applications in surface chemistry [159]. DNP NMR spectroscopy was recently applied on different types of thin films, including phosphorus-doped silicon [88], organolead halide perovskites [101] and organic semiconducting ones [111].

\section{High-Tech Opportunities beyond Conventional Methods}

In recent years, Solid-state NMR has observed significant developments and advancements that potentially revolutionized the field with respect to sensitivity and resolution. Hereby, we list the recently established techniques in solid-state NMR and explain explicitly the proper research directions that should be taken with respect to thin-film materials. The following methods are beyond the conventional known ones and include ultra-fast spinning, ultra-high magnetic fields, hyperpolarization techniques, pulse-field gradient NMR diffusion experiments and NMR relaxometry.

\subsection{Ultra-Fast MAS Spinning for ${ }^{1} H,{ }^{19} \mathrm{~F}$ and Heavy Spin- $\frac{1}{2}$ Nuclei}

Spectroscopic sensitivity is a critical parameter upon studying thin-film materials, and ultra-fast MAS spinning is an elegant method for achieving that. Although ${ }^{1} \mathrm{H}$ and ${ }^{19} \mathrm{~F}$ are expected to provide the highest sensitivity due to their high isotopic abundance and gyromagnetic ratios $\left(99.985 \%, 42.577 \mathrm{MHz} \cdot \mathrm{T}^{-1}\right.$ for $1 \mathrm{H}$ and $100 \%, 40.078 \mathrm{MHz} \cdot \mathrm{T}^{-1}$ for $\left.{ }^{19} \mathrm{~F}\right)$, these nuclei can benefit from ultra-fast MAS spinning in different ways. For example, conduct a set of proton-detection experiments (2D COSY, 2D INEPT, 3D INEPT-TOCSY and 2D RFDR techniques) to assign the resonance and determining the intermolecular packing [160-162], enable proton-detection of the mobile matrix, filter out the signals of the rigid domain [163], narrow the line-width so it is comparable to solution-state NMR, assign the resonances without perdeuteration of the sample $[164,165]$ and measure the ${ }^{19} \mathrm{~F}-{ }^{19} \mathrm{~F} /{ }^{1} \mathrm{H}$ distances beyond $1 \mathrm{~nm}$ [166-168] without disrupting the hydrogen bonds and intermolecular packing of the material by an appropriate sparsely fluorinate labeling $[168,169]$. Additionally, several quadrupole nuclei having short longitudinal relaxation times benefit from the rapid acquisition of proton-detected 2D HETCOR solid-state NMR spectra under MAS conditions to obtain various chemical information [170].

Heavy spin $-\frac{1}{2}$ nuclei in general, and Tin in particular, has extensive use in industry and academic research. Extracting chemical information about the different positions of the heavy spin- $\frac{1}{2}$ nuclei and the surrounding environments is essential. Ultra-fast MAS spinning experiments are considered extremely beneficial for their simplification of ultra-wide line NMR spectra, increased mass sensitivity and the extraction of chemical information, including chemical shift anisotropy, tensor parameters, and asymmetry [171].

\subsection{Ultra-High Magnetic Fields for Quadrupole Nuclei}

Recently, new types of ultra-high NMR magnets were revealed, in addition to the $1.3 \mathrm{GHz}(30.6 \mathrm{~T})$ hybrid high temperature and low-temperature superconducting magnets [172]. The newly developed series-connected hybrid magnet hits $1.5 \mathrm{GHz}(35.2 \mathrm{~T})$ and is an assembly of a superconducting outset and a resistive insert [173]. The development 
of ultra-high magnetic fields presents a unique opportunity for the investigation of exotic quadrupole nuclei [174] since quadrupole nuclei show high sensitivity under ultra-high magnetic fields leading to a dramatic change in the spectral line-width scale [175-177]. Ultra-high magnetic fields resolve to a certain extent the line-broadening associated with the second-order quadrupole coupling [106]. Applying multi-field experiments is a decisive exploration strategy for extracting structural information and exploring the chemical environment of exotic quadrupole nuclei such as ${ }^{2} \mathrm{H},{ }^{17} \mathrm{O},{ }^{33} \mathrm{~S}$ and ${ }^{35} \mathrm{Cl}$ in organic thin films and ${ }^{7} \mathrm{Li},{ }^{11} \mathrm{~B},{ }^{51} \mathrm{~V},{ }^{59} \mathrm{Co},{ }^{67} \mathrm{Zn},{ }^{71} \mathrm{Ga}$ and ${ }^{89} \mathrm{Yb}$ in inorganic ones.

The greatest challenge for quadrupole nuclei is the extraction of quantitative information; the expected route to achieve this is by rapid advancements in computational methods, which enables the calculation of NMR parameters and spectral interpretation. Moreover, the development of sensitivity boosting CryoProbes [178] and multichannel probes that are capable of decoupling multiple quadrupole nuclei for enhancing spectral resolution in inorganic thin films [59].

\subsection{Isotopic Enrichment of NMR Active Nuclei vs. Paramagnetic Doping for Sensitivity Boosting}

Isotopic enrichment provides significant spectral sensitivity compared to natural abundance; many NMR active nuclei could be used in their enriched form to grant the necessary sensitivity needed. Various biological compounds, such as amino acids and sugars, are ${ }^{13} \mathrm{C}$ and ${ }^{15} \mathrm{~N}$ labeled, which are used as precursors to produce uniformly or site-specific enriched proteins. Thin-film materials can also benefit from isotopic enrichment in several directions, including the ${ }^{29} \mathrm{Si}$-enriched precursors [179] for the production of organosilicate thin films, ${ }^{17} \mathrm{O}$-enriched [107] liquid $\mathrm{H}_{2}{ }^{17} \mathrm{O}$ or gaseous ${ }^{17} \mathrm{O}$ for the production of oxides, ceramics and catalysts, ${ }^{119} \mathrm{Sn}$-enriched strips [180] for the production of thin-film perovskites, ${ }^{43} \mathrm{Ca}$-enriched [181-183] carbonate thin films and several more opportunities [184].

On the other hand, paramagnetic relaxation reagents are widely used in solution-state NMR for their reducing relaxation properties and cost effectiveness, where the unpaired electrons originating from the paramagnetic species interact uniformly with the nuclear spins, thus enhancing the relaxation process $[185,186]$. The reduction of the relaxation time grants the quick accumulation of measuring scans leading to enhanced sensitivity in a time interval. Paramagnetic dopants are less effective in solid samples since the paramagnetic species can only interact with the neighboring nuclei but not with distant ones, thus leading to an inhomogeneous relaxation and partially resolved line-broadening [187,188]. Paramagnetic dopants were applied on thin organic semiconductors using vacuum-deposition techniques showing promising sensitivity boosting abilities when coupled to cross-polarization NMR techniques [189].

\subsection{Advanced Hyperpolarization Techniques}

Hyperpolarization techniques and especially natural abundance DNP ones have enhanced the NMR sensitivity drastically, but the efficiency of polarization in DNP experiments scales inversely to the external magnetic field, making high-field DNP ( $>9.4 \mathrm{~T})$ unlucrative. Most continuous-wave DNP experiments are operated at cryogenic temperatures and moderate magnetic fields in order to obtain the desired sensitivity enhancement. The future development pathways are in the combination of fast MAS and DNP NMR $[190,191]$ and overcoming the polarization vs. magnetic field/temperature correlation [188] by developing pulsed DNP techniques $[192,193]$ and new polarization strategies applicable at ambient temperatures. Several hyperpolarization techniques are available and could be applied on different thin-film materials depending on their magnetic properties, such as DNP surface-enhanced NMR spectroscopy for organosilicate materials [159,194-196], optical pumping used for phosphorus donor nuclei, ENDOR for paramagnetic nuclei and enhancement effect in magnets for ferromagnetic nuclei [197]. 
4.5. NMR Techniques beyond Spectroscopy (NMR Diffusometry, Fast Field Cycle NMR, Zero Field NMR, Magnetic Resonance Imaging)

NMR techniques are extended beyond spectroscopy limits to reach diffusometry, relaxometry and imaging techniques. NMR diffusometry is also known as pulse-field gradient NMR is capable of keeping track of molecular ensembles along their diffusion pathways for distances ranging between nano- to micrometers. Its unique ability to trace the rate of molecular transport vs the distance travel makes it an attractive technique to study not only the molecular displacement as a function of time and distance but also the diffusion anisotropy, impact of diffusion on chemical conversion in porous materials and domain size distribution [198]. NMR diffusometry with all the advantages it offers was barely used in thin-film research, but it has shown valuable applications in organic thin films, especially in bulk heterojunction organic photovoltaics [199], nafion [200] and liquid crystal thin films [201].

NMR relaxometry and imaging techniques can offer decisive information about the composition, nanomorphology and dynamics in thin-film research; these techniques have well established their foot in different areas of research and proved to be as valuable as NMR spectroscopy. Magnetic resonance imaging (MRI) has proven to be a versatile imaging technique. While it is remarkably used in biomedical research, it is also capable of producing images in material science. Magnetic resonance imaging forms an image of the measured environment solely depending on the density of protons in specific regions. Scanning with gradient coils causes the selected region to experience the specific magnetic field needed to absorb the energy, and the excited spins possess different relaxation behavior, which is measured by a receiving coil. Magnetic resonance imaging is a valuable technique for studying the solvent-matrix interactions not only in biomedical fields but also in material science and advanced film fields [202]. Meanwhile, Relaxometry refers to the study of relaxation variables under magnetic resonance and magnetic resonance imaging, where the relaxation rate of the nuclear spins is dependent on the mobility of the surrounding microscopic environment. The relaxation properties of the spins are also dependent on the applied magnetic field, where the sensitivity is enhanced for dynamic environments in strong magnetic fields and for rigid environments in low magnetic fields.

Solid-state NMR relaxometry has established its position in food science, including the determination of moisture content, solid fat content and much more [203] and shown to be complementary to traditional microscopic techniques in studying the phase morphology of blended materials used in semiconductive polymer-based devices [204].

\section{Summary, Concluding Remarks and Future Perspectives}

Solid-state NMR has established its position in different fields of science, starting from inorganic materials such as zeolites [205], inorganic polymers [206] and boranephosphane [207] passing through biological [208] and biotechnological systems [209] such as carbohydrates [210], proteins [211], biomembranes [212] and plant cell wall [213], environmental chemistry [214], and ending up with material science, including metal organic frameworks [215], perovskites [216], organic semiconductors [217] and functional nanomaterials [218]. Solid-state NMR spectroscopy, with its diverse techniques and measured nuclei, offers a wide range of valuable information on the geometric and electronic structure of advanced thin-film materials. Solid-state NMR is a promising technique in resolving as yet missing aspects of the molecular structure, polymorphism, packing and dynamics of thin films. Sensitivity is a great issue in solid-state NMR, placing it on the border, but recent technical and hardware advancements brought solutions to this that provided molecular information beyond expectations. In this article, we have reviewed the most advanced NMR strategies and hardware design to be used in studying advanced thin-film materials, but nowadays, there is no single technique capable of providing information on all different chemical levels. Ideally, the pursuit of integrated methods such as the combination of solidstate NMR advanced techniques with microscopic analysis and computational approaches can provide the most valuable information in studying advanced thin-film materials. 
Funding: This research received no external funding.

Acknowledgments: This work was supported by financial support from the Zernike Institute for Advanced Materials (ZIAM) at the University of Groningen, including funding from the Bonus Incentive Scheme (of the Dutch Ministry for Education, Culture and Science (OCW)). Special thanks to Zhenlei Zhang for the artwork provided in the graphical abstract.

Conflicts of Interest: All authors declare no conflict of interest.

\section{References}

1. Kindlund, H.; Sangiovanni, D.G.; Petrov, I.; Greene, J.E.; Hultman, L. A review of the intrinsic ductility and toughness of hard transition-metal nitride alloy thin films. Thin Solid Film. 2019, 688, 137479. [CrossRef]

2. Wang, X.; Xu, P.; Han, R.; Ren, J.; Li, L.; Han, N.; Xing, F.; Zhu, J. A review on the mechanical properties for thin film and block structure characterized by using nanoscratch test. Nano-Technol. Rev. 2019, 8, 628-644. [CrossRef]

3. Jansson, U.; Lewin, E. Carbon-containing multi-component thin films. Thin Solid Film. 2019, 688, 137411. [CrossRef]

4. Zhao, C.; Li, L.-Y.; Guo, M.-M.; Zheng, J. Functional polymer thin films designed for anti-fouling materials and biosensors. Chem. Pap. 2012, 66, 323-339. [CrossRef]

5. Spivack, M.A. Mechanical Properties of Very Thin Polymer Films. Rev. Sci. Instrum. 1972, 43, 985-990. [CrossRef]

6. Hu, C.; Guo, K.; Li, Y.; Gu, Z.; Quan, J.; Zhang, S.; Zheng, W. Optical coatings of durability based on transition metal nitrides. Thin Solid Film. 2019, 688, 137339. [CrossRef]

7. Moon, D.-B.; Lee, J.; Roh, E.; Lee, N.-E. Three-dimensional out-of-plane geometric engineering of thin films for stretchable electronics: A brief review. Thin Solid Film. 2019, 688, 137435. [CrossRef]

8. Serrano, A.; de la Fuente, O.R.; García, M.A. Extended and localized surface plasmons in annealed Au films on glass substrates. J. Appl. Phys. 2010, 108, 074303. [CrossRef]

9. Liu, X.; Feng, Y.; Chen, K.; Zhu, B.; Zhao, J.; Jiang, T. Planar surface plasmonic waveguide devices based on symmetric corrugated thin film structures. Opt. Express 2014, 22, 20107. [CrossRef]

10. Foley, J.J., IV; Harutyunyan, H.; Rosenmann, D.; Divan, R.; Wiederrecht, G.P.; Gray, S.K. When are Surface Plasmon Polaritons Excited in the Kretschmann-Raether Configuration? Sci. Rep. 2015, 5, 9929. [CrossRef]

11. Branco, R.; Sousa, T.; Piedade, A.P.; Morais, P.V. Immobilization of Ochrobactrum tritici As5 on PTFE thin films for arsenite biofiltration. Chemosphere 2016, 146, 330-337. [CrossRef] [PubMed]

12. Khlyustova, A.; Cheng, Y.; Yang, R. Vapor-deposited functional polymer thin films in biological applications. J. Mater. Chem. B 2020, 8, 6588-6609. [CrossRef] [PubMed]

13. Yu, P.; Yao, Y.; Wu, J.; Niu, X.; Rogach, A.L.; Wang, Z. Effects of Plasmonic Metal Core -Dielectric Shell Nanoparticles on the Broadband Light Absorption Enhancement in Thin Film Solar Cells. Sci. Rep. 2017, 7, 7696. [CrossRef]

14. Terry, M.L.; Straub, A.; Inns, D.; Song, D.; Aberle, A.G. Large open-circuit voltage improvement by rapid thermal annealing of evaporated solid-phase-crystallized thin-film silicon so-lar cells on glass. Appl. Phys. Lett. 2005, 86, 172108. [CrossRef]

15. Nayak, P.K.; Mahesh, S.; Snaith, H.J.; Cahen, D. Photovoltaic solar cell technologies: Analysing the state of the art. Nat. Rev. Mater. 2019, 4, 269-285. [CrossRef]

16. Mukanova, A.; Jetybayeva, A.; Myung, S.-T.; Kim, S.-S.; Bakenov, Z. A mini-review on the development of Si-based thin film anodes for Li-ion batteries. Mater. Today Energy 2018, 9, 49-66. [CrossRef]

17. Yang, G.; Abraham, C.; Ma, Y.; Lee, M.; Helfrick, E.; Oh, D.; Lee, D. Advances in Materials De-sign for All-Solid-state Batteries: From Bulk to Thin Films. Appl. Sci. 2020, 10, 4727. [CrossRef]

18. Moitzheim, S.; Put, B.; Vereecken, P.M. Advances in 3D Thin-Film Li-Ion Batteries. Adv. Mater. Interfaces 2019, 6, 1900805. [CrossRef]

19. Jilani, A.; Abdel-wahab, M.S.; Hammad, A.H. Advance Deposition Techniques for Thin Film and Coating. In Modern Technologies for Creating the Thin-Film Systems and Coatings; Nikitenkov, N.N., Ed.; Intech: London, UK, 2017; pp. 137-149. [CrossRef]

20. Campbell, D.S. Preparation Methods for Thin Films. In Physics of Nonmetallic Thin Films; Dupuy, C.H.S., Cachard, A., Eds.; Springer US: Boston, MA, USA, 1976; pp. 9-48. [CrossRef]

21. Mehran, Q.M.; Fazal, M.A.; Bushroa, A.R.; Rubaiee, S. A Critical Review on Physical Vapor Deposition Coatings Applied on Different Engine Components. Crit. Rev. Solid State Mater. Sci. 2018, 43, 158-175. [CrossRef]

22. Baptista, A.; Silva, F.; Porteiro, J.; Míguez, J.; Pinto, G. Sputtering Physical Vapour Deposition (PVD) Coatings: A Critical Review on Process Improvement and Market Trend Demands. Coatings 2018, 8, 402. [CrossRef]

23. Hassanien, A.S.; Akl, A.A. Effect of Se addition on optical and electrical properties of chal-cogenide CdSSe thin films. Superlattices Microstruct. 2016, 89, 153-169. [CrossRef]

24. Hannachi, A.; Segura, H. Maghraoui-Meherzi, Growth of manganese sulfide $(\alpha-\mathrm{MnS})$ thin films by thermal vacuum evaporation: Structural, morphological and optical properties. Mater. Chem. Phys. 2016, 181, 326-332. [CrossRef]

25. Ananth Kumar, R.T.; Das, C.; Chithra Lekha, P.; Asokan, S.; Sanjeeviraja, C.; Pathinettam Padiyan, D. Enhancement in threshold voltage with thickness in memory switch fabricated using $\mathrm{GeSe}_{1.5} \mathrm{~S}_{0.5}$ thin films. J. Alloy. Compd. 2014, 615, 629-635. [CrossRef]

26. Malligavathy, M.; Ananth Kumar, R.T.; Das, C.; Asokan, S.; Pathinettam Padiyan, D. Growth and characteristics of amorphous $\mathrm{Sb}_{2} \mathrm{Se}_{3}$ thin films of various thicknesses for memory switching applications. J. Non-Cryst. Solids 2015, 429, 93-97. [CrossRef] 
27. Abdel Rafea, M.; Farid, H. Phase change and optical band gap behavior of $\mathrm{Se}_{0.8} \mathrm{~S}_{0.2}$ chalcogenide glass films. Mater. Chem. Phys. 2009, 113, 868-872. [CrossRef]

28. Sangeetha, B.G.; Joseph, C.M.; Suresh, K. Preparation and characterization of $\mathrm{Ge}_{1} \mathrm{Sb}_{2} \mathrm{Te}_{4}$ thin films for phase change memory applications. Microelectron. Eng. 2014, 127, 77-80. [CrossRef]

29. Salomé, P.M.P.; Rodriguez-Alvarez, H.; Sadewasser, S. Incorporation of alkali metals in chalcogenide solar cells. Sol. Energy Mater. Sol. Cells 2015, 143, 9-20. [CrossRef]

30. Merkel, J.J.; Sontheimer, T.; Rech, B.; Becker, C. Directional growth and crystallization of silicon thin films prepared by electronbeam evaporation on oblique and textured surfaces. J. Cryst. Growth 2013, 367, 126-130. [CrossRef]

31. Yang, B.; Duan, H.; Zhou, C.; Gao, Y.; Yang, J. Ordered nanocolumn-array organic semiconductor thin films with controllable molecular orientation. Appl. Surf. Sci. 2013, 286, 104-108. [CrossRef]

32. Schulz, U.; Terry, S.G.; Levi, C.G. Microstructure and texture of EB-PVD TBCs grown under different rotation modes. Mater. Sci. Eng. A 2003, 360, 319-329. [CrossRef]

33. Ashfold, M.N.R.; Claeyssens, F.; Fuge, G.M.; Henley, S.J. Pulsed laser ablation and deposition of thin films. Chem. Soc. Rev. 2004, 33, 23-31. [CrossRef]

34. Lynds, L.; Weinberger, B.R.; Potrepka, D.M.; Peterson, G.G.; Lindsay, M.P. High temperature superconducting thin films: The physics of pulsed laser ablation. Phys. C Supercond. 1989, 159, 61-69. [CrossRef]

35. Angusmacleod, H. Recent developments in deposition techniques for optical thin films and coatings. In Optical Thin Films and Coatings; Elsevier: Amsterdam, The Netherlands, 2013; pp. 3-25. [CrossRef]

36. Barranco, A.; Borras, A.; Gonzalez-Elipe, A.R.; Palmero, A. Perspectives on oblique angle deposition of thin films: From fundamentals to devices. Prog. Mater. Sci. 2016, 76, 59-153. [CrossRef]

37. Morosanu, C.; Dumitru, V.; Cimpoiasu, E.; Nenu, C. Comparison Between DC and RF Magnetron Sputtered Aluminum Nitride Films. In Diamond Based Composites; Prelas, M.A., Benedictus, A., Lin, L.-T.S., Po-povici, G., Gielisse, P., Eds.; Springer: Dordrecht, The Netherlands, 1997; pp. 127-132. [CrossRef]

38. Dumitru, V.; Morosanu, C.; Sandu, V.; Stoica, A. Optical and structural differences between $\mathrm{RF}_{\text {and } \mathrm{DC}} \mathrm{Al}_{\mathrm{x}} \mathrm{N}_{\mathrm{y}} \mathrm{magnetron}$ sputtered films. Thin Solid Film. 2000, 359, 17-20. [CrossRef]

39. Mersagh Dezfuli, S.; Sabzi, M. Deposition of self-healing thin films by the sol-gel method: A review of layer-deposition mechanisms and activation of self-healing mechanisms. Appl. Phys. A 2019, 125, 557. [CrossRef]

40. Nagyal, L.; Gupta, S.S.; Singh, R.; Kumar, A.; Chaudhary, P. Sol-Gel Deposition of Thin Films. In Digital Encyclopedia of Applied Physics; Wiley-VCH Verlag GmbH \& Co. KGaA, Ed.; Wiley-VCH Verlag GmbH \& Co. KGaA: Weinheim, Germany, $2019 ;$ pp. 1-18. [CrossRef]

41. Brinker, C.J.; Hurd, A.J.; Schunk, P.R.; Frye, G.C.; Ashley, C.S. Review of sol-gel thin film formation. J. Non-Cryst. Solids 1992, 147-148, 424-436. [CrossRef]

42. Livage, J.; Sanchez, C.; Henry, M.; Doeuff, S. The chemistry of the sol-gel process. Solid State Ion. 1989, 32-33, 633-638. [CrossRef]

43. Mattevi, C.; Kim, H.; Chhowalla, M. A review of chemical vapour deposition of graphene on copper. J. Mater. Chem. 2011, 21, 3324-3334. [CrossRef]

44. Cai, Z.; Liu, B.; Zou, X.; Cheng, H.-M. Chemical Vapor Deposition Growth and Applications of Two-Dimensional Materials and Their Heterostructures. Chem. Rev. 2018, 118, 6091-6133. [CrossRef]

45. Sun, L.; Yuan, G.; Gao, L.; Yang, J.; Chhowalla, M.; Gharahcheshmeh, M.H.; Gleason, K.K.; Choi, Y.S.; Hong, B.H.; Liu, Z. Chemical vapour deposition. Nat. Rev. Methods Primers 2021, 1, 5. [CrossRef]

46. Chen, N.; Kim, D.H.; Kovacik, P.; Sojoudi, H.; Wang, M.; Gleason, K.K. Polymer Thin Films and Surface Modification by Chemical Vapor Deposition: Recent Progress. Annu. Rev. Chem. Biomol. Eng. 2016, 7, 373-393. [CrossRef]

47. Danglad-Flores, J.; Eickelmann, S.; Riegler, H. Deposition of polymer films by spin casting: A quantitative analysis. Chem. Eng. Sci. 2018, 179, 257-264. [CrossRef]

48. Taylor, J.F. Spin coating: An overview. Met. Finish. 2001, 99, 16-21. [CrossRef]

49. Mavukkandy, M.O.; McBride, S.A.; Warsinger, D.M.; Dizge, N.; Hasan, S.W.; Arafat, H.A. Thin film deposition techniques for polymeric membranes-A review. J. Membr. Sci. 2020, 610, 118258. [CrossRef]

50. Tang, X.; Yan, X. Dip-coating for fibrous materials: Mechanism, methods and applications. J. Sol. Gel Sci. Technol. 2017, 81, 378-404. [CrossRef]

51. Riau, A.K.; Mondal, D.; Setiawan, M.; Palaniappan, A.; Yam, G.H.F.; Liedberg, B.; Venkatraman, S.S.; Mehta, J.S. Functionalization of the Polymeric Surface with Bioceramic Nanoparticles via a Novel, Nonthermal Dip Coating Method. ACS Appl. Mater. Interfaces 2016, 8, 35565-35577. [CrossRef] [PubMed]

52. Guire, M.R.D.; Bauermann, L.P.; Parikh, H.; Bill, J. Chemical Bath Deposition. In Chemical Solution Deposition of Functional Ox-ide Thin Films; Schneller, T., Waser, R., Kosec, M., Payne, D., Eds.; Springer: Vienna, Austria, 2013; pp. 319-339. [CrossRef]

53. Contreras-Rascón, J.I.; Díaz-Reyes, J.; Luna-Suárez, S.; Carrillo-Torres, R.C.; Sánchez-Zeferino, R. Characterisation of chemical bath deposition $\mathrm{PbS}$ nanofilms using polyethylene-imine, triethanolamine and ammonium nitrate as complexing agents. Thin Solid Film. 2019, 692, 137609. [CrossRef]

54. Mooney, J.B.; Radding, S.B. Spray Pyrolysis Processing. Annu. Rev. Mater. Sci. 1982, 12, 81-101. [CrossRef]

55. Falcony, C.; Aguilar-Frutis, M.; García-Hipólito, M. Spray Pyrolysis Technique; High-K Die-lectric Films and Luminescent Materials: A Review. Micromachines 2018, 9, 414. [CrossRef] 
56. Baer, D.R.; Thevuthasan, S. Characterization of Thin Films and Coatings. In Handbook of Deposition Technologies for Films and Coatings; Elsevier: Amsterdam, The Netherlands, 2010; pp. 749-864. [CrossRef]

57. Pourjamal, S.; Mäntynen, H.; Jaanson, P.; Rosu, D.M.; Hertwig, A.; Manoocheri, F.; Ikonen, E. Characterization of thin-film thickness. Metrologia 2014, 51, S302-S308. [CrossRef]

58. Abbas, A.N.; Liu, G.; Narita, A.; Orosco, M.; Feng, X.; Müllen, K.; Zhou, C. Deposition, Characterization, and Thin-Film-Based Chemical Sensing of Ultra-long Chemically Synthesized Graphene Nanoribbons. J. Am. Chem. Soc. 2014, 136, 7555-7558. [CrossRef]

59. Reif, B.; Ashbrook, S.E.; Emsley, L.; Hong, M. Solid-state NMR spectroscopy. Nat. Rev. Methods Primers 2021, 1, 2. [CrossRef]

60. Laws, D.D.; Bitter, H.-M.L.; Jerschow, A. Solid-state NMR spectroscopic methods in chemistry. Angew. Chem. 2002, 34, 3096-3129. [CrossRef]

61. De Almeida, N.E.; Paul, D.K.; Karan, K.; Goward, G.R. ${ }^{1}$ H Solid-State NMR Study of Nanothin Nafion Films. J. Phys. Chem. C 2015, 119, 1280-1285. [CrossRef]

62. Pfeffermann, M.; Dong, R.; Graf, R.; Zajaczkowski, W.; Gorelik, T.; Pisula, W.; Narita, A.; Müllen, K.; Feng, X. Free-Standing Monolayer Two-Dimensional Supramolecular Organic Framework with Good Internal Order. J. Am. Chem. Soc. 2015, 137, 14525-14532. [CrossRef] [PubMed]

63. Blum, F.D. NMR Studies of Organic Thin films. In Annual Reports on NMR Spectroscopy; Elsevier: Amsterdam, The Netherlands, 1994; pp. 277-321. [CrossRef]

64. Jagadeesh, B.; Demco, D.E.; Blümich, B. Surface induced order and dynamic heterogeneity in ultra-thin polymer films: A ${ }^{1} \mathrm{H}$ multiple-quantum NMR study. Chem. Phys. Lett. 2004, 393, 416-420. [CrossRef]

65. Wu, X.; Yang, S.; Samuelson, L.A.; Cholli, A.L.; Kumar, J. Conformation of Azobenzene-Modified Poly( $\alpha$-L-Glutamate) (AZOPLGA) in Thin Films: Solid State NMR Studies. J. Macromol. Sci. Part A 2004, 41, 1359-1368. [CrossRef]

66. Alam, T.M.; Friedmann, T.A.; Schultz, P.A.; Sebastiani, D. Low temperature annealing in tetrahedral amorphous carbon thin films observed by ${ }^{13} \mathrm{C}$ NMR spectroscopy. Phys. Rev. B 2003, 67, 245309. [CrossRef]

67. Dalvi, L.C.; Laine, C.; Virtanen, T.; Liitiä, T.; Tenhunen, T.-M.; Orelma, H.; Tammelin, T.; Tamminen, T. Study of xylan and cellulose interactions monitored with solid-state NMR and QCM-D. Holzforschung 2020, 74, 643-653. [CrossRef]

68. Yu, Y.-Y.; Chen, C.-Y.; Chen, W.-C. Synthesis and characterization of organic-inorganic hybrid thin films from poly(acrylic) and monodispersed colloidal silica. Polymer 2003, 44, 593-601. [CrossRef]

69. Rivillon, S.; Auroy, P.; Deloche, B. Chain Segment Order in Polymer Thin Films on a Non-adsorbing Surface: A NMR Study. Phys. Rev. Lett. 2000, 84, 499-502. [CrossRef]

70. Nieuwendaal, R.C.; DeLongchamp, D.M.; Richter, L.J.; Snyder, C.R.; Jones, R.L.; Engmann, S.; Herzing, A.; Heeney, M.; Fei, Z.; Sieval, A.B.; et al. Characterization of Interfacial Structure in Polymer-Fullerene Bulk Heterojunctions via ${ }^{13} \mathrm{C}\left\{{ }^{2} \mathrm{H}\right\}$ Rotational Echo Double Resonance NMR. Phys. Rev. Lett. 2018, 121, 026101. [CrossRef]

71. Marple, M.A.T.; Wynn, T.A.; Cheng, D.; Shimizu, R.; Mason, H.E.; Meng, Y.S. Local Structure of Glassy Lithium Phosphorus Oxynitride Thin Films: A Combined Experimental and Ab Initio Approach. Angew. Chem. 2020, 59, 22185-22193. [CrossRef] [PubMed]

72. Stallworth, P.E.; Vereda, F.; Greenbaum, S.G.; Haas, T.E.; Zerigian, P.; Goldner, R.B. Solid-State NMR Studies of Lithium Phosphorus Oxynitride Films Prepared by Nitrogen Ion Beam-Assisted Deposition. J. Electrochem. Soc. 2005, 152 , A516. [CrossRef]

73. MacFarlane, W.A.; Morris, G.D.; Beals, T.R.; Chow, K.H.; Baartman, R.A.; Daviel, S.; Dunsiger, S.R.; Hatakeyama, A.; Kreitzman, S.R.; Levy, C.D.P.; et al. 8Li $\beta-N M R$ in thin metal films. Physica B 2003, 326, 213-216. [CrossRef]

74. Mukuda, H.; Tsuchida, T.; Harada, A.; Kitaoka, Y.; Takenouchi, T.; Takano, Y.; Nagao, M.; Sakaguchi, I.; Kawarada, H. ${ }^{11}$ B-NMR study in boron-doped diamond films. Sci. Technol. Adv. Mater. 2006, 7, S37-S40. [CrossRef]

75. Yesinowski, J.P. ${ }^{69,71} \mathrm{Ga}$ and ${ }^{14} \mathrm{~N}$ high-field NMR of gallium nitride films: ${ }^{69,71} \mathrm{Ga}$ and ${ }^{14} \mathrm{~N}$ high-field NMR of gallium nitride films. Phys. Stat. Sol. 2005, 2, 2399-2402. [CrossRef]

76. Hope, M.A.; Zhang, B.; Zhu, B.; Halat, D.M.; MacManus-Driscoll, J.L.; Grey, C.P. Revealing the Structure and Oxygen Transport at Interfaces in Complex Oxide Heterostructures via ${ }^{17}$ O NMR Spectroscopy. Chem. Mater. 2020, 32, 7921-7931. [CrossRef]

77. Won, S.; Saun, S.-B.; Lee, S.; Lee, S.; Kim, K.; Han, Y. NMR Spectroscopy for Thin Films by Magnetic Resonance Force Microscopy. Sci. Rep. 2013, 3, 3189. [CrossRef] [PubMed]

78. Aimi, K.; Ando, S. Solid-state ${ }^{19} \mathrm{~F}$ MAS and ${ }^{1} \mathrm{H} \rightarrow{ }^{19} \mathrm{~F} \mathrm{CP} / \mathrm{MAS}$ NMR study of the phase-transition behavior of vinylidene fluoride-trifluoroethylene copolymers: 2. semi-crystalline films of VDF 75\% copolymer. Polym. J. 2012, 44, 786-794. [CrossRef]

79. Koseki, Y.; Aimi, K.; Ando, S. Crystalline structure and molecular mobility of PVDF chains in PVDF/PMMA blend films analyzed by solid-state 19F MAS NMR spectroscopy. Polym. J. 2012, 44, 757-763. [CrossRef]

80. Cui, J.; Kast, M.G.; Hammann, B.A.; Afriyie, Y.; Woods, K.N.; Plassmeyer, P.N.; Perkins, C.K.; Ma, Z.L.; Keszler, D.A.; Page, C.J.; et al. Aluminum Oxide Thin Films from Aqueous Solutions: Insights from Solid-State NMR and Dielectric Response. Chem. Mater. 2018, 30, 7456-7463. [CrossRef]

81. Mazaj, M.; Costacurta, S.; Zabukovec Logar, N.; Mali, G.; Novak Tušar, N.; Innocenzi, P.; Malfatti, L.; Thibault-Starzyk, F.; Amenitsch, H.; Kaučič, V.; et al. Mesoporous Aluminophosphate Thin Films with Cubic Pore Arrangement. Langmuir 2008, 24, 6220-6225. [CrossRef] [PubMed] 
82. Sarou-Kanian, V.; Gleizes, A.N.; Florian, P.; Samélor, D.; Massiot, D.; Vahlas, C. Temperature-Dependent 4-, 5- and 6-Fold Coordination of Aluminum in MOCVD-Grown Amorphous Alumina Films: A Very High Field 27 Al-NMR study. J. Phys. Chem. C 2013, 117, 21965-21971. [CrossRef]

83. Kim, N.; Bassiri, R.; Fejer, M.M.; Stebbins, J.F. The structure of ion beam sputtered amorphous alumina films and effects of Zn doping: High-resolution ${ }^{27} \mathrm{Al}$ NMR. J. Non-Cryst. Solids 2014, 405, 1-6. [CrossRef]

84. Landskron, K. Periodic Mesoporous Organosilicas Containing Interconnected $\left[\mathrm{Si}\left(\mathrm{CH}_{2}\right)\right]_{3}$ Rings. Science 2003, 302, 266-269. [CrossRef]

85. Hatton, B.D.; Landskron, K.; Whitnall, W.; Perovic, D.D.; Ozin, G.A. Spin-Coated Periodic Mesoporous Organosilica Thin Films? Towards a New Generation of Low-Dielectric-Constant Materials. Adv. Funct. Mater. 2005, 15, 823-829. [CrossRef]

86. Pallister, P.J.; Barry, S.T. Surface chemistry of group 11 atomic layer deposition precursors on silica using solid-state nuclear magnetic resonance spectroscopy. J. Chem. Phys. 2017, 146, 052812. [CrossRef] [PubMed]

87. Passos, A.A.; Tavares, M.I.B.; Neto, R.C.P.; Ferreira, A.G. The Use of Solid-State NMR to Evaluate EVA/Silica FILMs. J. Nano R. 2012, 18-19, 219-226. [CrossRef]

88. Järvinen, J.; Ahokas, J.; Sheludyakov, S.; Vainio, O.; Lehtonen, L.; Vasiliev, S.; Zvezdov, D.; Fujii, Y.; Mitsudo, S.; Mizusaki, T.; et al. Efficient dynamic nu-clear polarization of phosphorus in silicon in strong magnetic fields and at low temperatures. Phys. Rev. $B$ 2014, 90, 214401. [CrossRef]

89. Stuart, B.W.; Grant, C.A.; Stan, G.E.; Popa, A.C.; Titman, J.J.; Grant, D.M. Gallium incorporation into phosphate-based glasses: Bulk and thin film properties. J. Mech. Behav. Biomed. Mater. 2018, 82, 371-382. [CrossRef]

90. Riedi, P.C.; Thomson, T.; Tomka, G.J. Chapter 2 NMR of thin magnetic films and superlattices. In Handbook of Magnetic Materials; Elsevier: Amsterdam, The Netherlands, 1999; pp. 97-258. [CrossRef]

91. Bibes, M.; Balcells, L.; Valencia, S.; Fontcuberta, J.; Wojcik, M.; Jedryka, E.; Nadolski, S. Nanoscale Multiphase Separation at $\mathrm{La}_{2 / 3} \mathrm{Ca}_{1 / 3} \mathrm{MnO}_{3} / \mathrm{SrTiO}_{3}$ Interfaces. Phys. Rev. Lett. 2001, 87, 067210. [CrossRef] [PubMed]

92. Dang, K.L.; Veillet, P.; Sakakima, H.; Krishnan, R. NMR studies of compositionally modulated Co/Mn thin films. J. Phys. F Met. Phys. 1986, 16, 93-97. [CrossRef]

93. Wieldraaijer, H.; de Jonge, W.J.M.; Kohlhepp, J.T. ${ }^{59} \mathrm{Co}$ NMR observation of monolayer re-solved hyperfine fields in ultrathin epitaxial FCT-Co(001) films. J. Magn. Magn. Mater. 2005, 286, 390-393. [CrossRef]

94. Wojcik, M.; Jay, J.P.; Panissod, P.; Jedryka, E.; Dekoster, J.; Langouche, G. New phases and chemical short range order in co-deposited CoFe thin films with bcc structure: An NMR study. Z. Phys. B Condens. Matter. 1997, 103, 5-12. [CrossRef]

95. Thomson, T.; Riedi, P.C.; Platt, C.L.; Berkowitz, A.E. NMR studies of sputtered CoFe alloy thin films. IEEE Trans. Magn 1998, 34, 1045-1047. [CrossRef]

96. Hammann, B.A.; Ma, Z.L.; Wentz, K.M.; Kamunde-Devonish, M.K.; Johnson, D.W.; Hayes, S.E. Structural study by solid-state 71 Ga NMR of thin film transistor precursors. Dalton Trans. 2015, 44, 17652-17659. [CrossRef]

97. Degen, C.; Tomaselli, M.; Meier, B.H.; Voncken, M.M.A.J.; Kentgens, A.P.M. NMR investigation of atomic ordering in $\mathrm{Al}_{\mathrm{x}} \mathrm{Ga}_{1-\mathrm{x}}$ as thin films. Phys. Rev. B 2004, 69, 193303. [CrossRef]

98. Chandran, C.V.; Schreuders, H.; Dam, B.; Janssen, J.W.G.; Bart, J.; Kentgens, A.P.M.; van Bentum, P.J.M. Solid-State NMR Studies of the Photochromic Effects of Thin Films of Oxygen-Containing Yttrium Hydride. J. Phys. Chem. C 2014, 118, 22935-22942. [CrossRef]

99. Raftery, D.; Long, H.; Reven, L.; Tang, P.; Pines, A. NMR of optically pumped xenon thin films. Chem. Phys. Lett. 1992, 191, 385-390. [CrossRef]

100. Nossov, A.; Haddad, E.; Guenneau, F.; Mignon, C.; Gédéon, A.; Grosso, D.; Babonneau, F.; Bonhomme, C.; Sanchez, C. The first direct probing of porosity on supported mesoporous silica thin films through hyperpolarised ${ }^{129}$ Xe NMR. Chem. Commun. 2002, 2476-2477. [CrossRef]

101. Hanrahan, M.P.; Men, L.; Rosales, B.A.; Vela, J.; Rossini, A.J. Sensitivity-Enhanced ${ }^{207} \mathrm{~Pb}$ Solid-State NMR Spectroscopy for the Rapid, Non-Destructive Characterization of Organolead Halide Perovskites. Chem. Mater. 2018, 30, 7005-7015. [CrossRef]

102. Alam, T.M.; Friedmann, T.A.; Jurewicz, A.J.G. Solid State ${ }^{13}$ C MAS NMR Investigations of Amorphous Carbon Thin Films. In Thin Films: Preparation, Characterization, Applications; Soriaga, M.P., Stickney, J., Bottomley, L.A., Kim, Y.-G., Eds.; Springer: Boston, MA, USA, 2002; pp. 277-289. [CrossRef]

103. Yuan, K.; Hu, T.; Xu, Y.; Graf, R.; Brunklaus, G.; Forster, M.; Chen, Y.; Scherf, U. Engineering the Morphology of Carbon Materials: 2D Porous Carbon Nanosheets for High-Performance Supercapacitors. ChemElectroChem 2016, 3, 822-828. [CrossRef]

104. Yuan, K.; Hu, T.; Xu, Y.; Graf, R.; Shi, L.; Forster, M.; Pichler, T.; Riedl, T.; Chen, Y.; Scherf, U. Nitrogen-doped porous carbon/graphene nanosheets derived from two-dimensional conjugated microporous polymer sandwiches with promising capacitive performance. Mater. Chem. Front. 2017, 1, 278-285. [CrossRef]

105. Merwin, L.H.; Johnson, C.E.; Weimer, W.A. ${ }^{13}$ C NMR investigation of CVD diamond: Correlation of NMR and Raman spectral linewidths. J. Mater. Res. 1994, 9, 631-635. [CrossRef]

106. Keeler, E.G.; Michaelis, V.K.; Colvin, M.T.; Hung, I.; Gor'kov, P.L.; Cross, T.A.; Gan, Z.; Griffin, R.G. ${ }^{17}$ O MAS NMR Correlation Spectroscopy at High Magnetic Fields. J. Am. Chem. Soc. 2017, 139, 17953-17963. [CrossRef]

107. Ashbrook, S.E.; Smith, M.E. Solid state ${ }^{17} \mathrm{O}$ NMR — an introduction to the background principles and applications to inorganic materials. Chem. Soc. Rev. 2006, 35, 718-735. [CrossRef] 
108. Grover, R.; Srivastava, R.; Rana, O.; Mehta, D.S.; Kamalasanan, M.N. New Organic Thin-Film Encapsulation for Organic Light Emitting Diodes. JEAS 2011, 1, 23-28. [CrossRef]

109. Yeh, N.; Yeh, P. Organic solar cells: Their developments and potentials. Renew. Sustain. Energy Rev. 2013, 21, 421-431. [CrossRef]

110. Chandar Shekar, B.; Lee, J.; Rhee, S.-W. Organic thin film transistors: Materials, processes and devices. Korean J. Chem. Eng. 2004, 21, 267-285. [CrossRef]

111. Suzuki, K.; Kubo, S.; Aussenac, F.; Engelke, F.; Fukushima, T.; Kaji, H. Analysis of Molecular Orientation in Organic Semiconducting Thin Films Using Static Dynamic Nuclear Polarization Enhanced Solid-State NMR Spectroscopy. Angew. Chem. 2017, 56, 14842-14846. [CrossRef]

112. Chaudhari, R.; Griffin, J.M.; Broch, K.; Lesage, A.; Lemaur, V.; Dudenko, D.; Olivier, Y.; Sirringhaus, H.; Emsley, L.; Grey, C.P. Donor-acceptor stacking arrangements in bulk and thin-film high-mobility conjugated polymers characterized using molecular modelling and MAS and surface-enhanced solid-state NMR spectroscopy. Chem. Sci. 2017, 8, 3126-3136. [CrossRef]

113. Park, S.-H.; Alammar, A.; Fulop, Z.; Pulido, B.A.; Nunes, S.P.; Szekely, G. Hydrophobic thin film composite nanofiltration membranes derived solely from sustainable sources. Green Chem. 2021, 23, 1175-1184. [CrossRef]

114. Chisca, S.; Marchesi, T.; Falca, G.; Musteata, V.-E.; Huang, T.; Abou-Hamad, E.; Nunes, S.P. Organic solvent and thermal resistant polytriazole membranes with enhanced mechanical properties cast from solutions in non-toxic solvents. J. Membr. Sci. 2020, 597, 117634. [CrossRef]

115. Begni, F.; Paul, G.; Lasseuguette, E.; Mangano, E.; Bisio, C.; Ferrari, M.-C.; Gatti, G. Synthetic Saponite Clays as Additives for Reducing Aging Effects in PIM1 Membranes. ACS Appl. Polym. Mater. 2020, 2, 3481. [CrossRef]

116. Ren, D.; Jin, Y.-T.; Liu, T.-Y.; Wang, X. Phenanthroline-Based Polyarylate Porous Membranes with Rapid Water Transport for Metal Cation Separation. ACS Appl. Mater. Interfaces 2020, 12, 7605-7616. [CrossRef] [PubMed]

117. Andrew, E.R.; Bradbury, A.; Eades, R.G. Nuclear Magnetic Resonance Spectra from a Crystal rotated at High Speed. Nature 1958, 182, 1659. [CrossRef]

118. Andrew, E.R.; Bradbury, A.; Eades, R.G. Removal of Dipolar Broadening of Nuclear Magnetic resonance Spectra of Solids by Specimen Rotation. Nature 1959, 183, 1802-1803. [CrossRef]

119. Alam, T.M.; Fan, H. Investigation of Templated Mesoporous Silicate Thin Films Using High Speed, Solid-State ${ }^{1} \mathrm{H}$ MAS and Double Quantum NMR Spectroscopy. Macromol. Chem. Phys. 2003, 204, 2023-2030. [CrossRef]

120. Steinbeck, C.A.; Ernst, M.; Meier, B.H.; Chmelka, B.F. Anisotropic Optical Properties and Structures of Block Copolymer/Silica Thin Films Containing Aligned Porphyrin J-Aggregates. J. Phys. Chem. C 2008, 112, 2565-2573. [CrossRef]

121. Lu, D.; Baek, D.J.; Hong, S.S.; Kourkoutis, L.F.; Hikita, Y.; Hwang, H.Y. Synthesis of freestanding single-crystal perovskite films and heterostructures by etching of sacrificial water-soluble layers. Nat. Mater. 2016, 15, 1255-1260. [CrossRef]

122. Liang, X.; Sperling, B.A.; Calizo, I.; Cheng, G.; Hacker, C.A.; Zhang, Q.; Obeng, Y.; Yan, K.; Peng, H.; Li, Q.; et al. Toward Clean and Crackless Transfer of Graphene. ACS Nano 2011, 5, 9144-9153. [CrossRef]

123. VanderHart, L.; Prabhu, V.M.; Lavery, K.A.; Dennis, C.L.; Rao, A.B.; Lin, E.K. Thin-film solid-state proton NMR measurements using a synthetic mica substrate: Polymer blends. J. Magn. Reson. 2009, 201, 100-110. [CrossRef]

124. Inukai, M.; Noda, Y.; Takeda, K. Nondestructive high-resolution solid-state NMR of rotating thin films at the magic-angle. J. Magn. Reson. 2011, 213, 192-195. [CrossRef] [PubMed]

125. Inukai, M.; Takeda, K. Studies on multiple-quantum magic-angle-spinning NMR of half-integer quadrupolar nuclei under strong rf pulses with a microcoil. Concepts Magn. Reson. B 2008, 33, 115-123. [CrossRef]

126. Janssen, H.; Brinkmann, A.; Kentgens, A.P.M. Microcoil High-Resolution Magic Angle Spinning NMR Spectroscopy. J. Am. Chem. Soc. 2006, 128, 8722-8723. [CrossRef] [PubMed]

127. Yamauchi, K.; Asakura, T. Development of MicroMAS NMR Probehead for Mass-limited Solid-state Samples. Chem. Lett. 2006, 35, 426-427. [CrossRef]

128. Wensink, H.; Benito-Lopez, F.; Hermes, D.C.; Verboom, W.; Gardeniers, H.J.G.E.; Reinhoudt, D.N.; van den Berg, A. Measuring reaction kinetics in a lab on a chip by microcoil NMR. Lab. Chip 2005, 5, 280-284. [CrossRef] [PubMed]

129. Massin, C.; Boero, G.; Vincent, F.; Abenhaim, J.; Besse, P.-A.; Popovic, R.S. High-Q factor RF planar microcoils for micro-scale NMR spectroscopy. Sens. Actuators A Phys. 2002, 97-98, 280-288. [CrossRef]

130. Dechow, J.; Forchel, A.; Lanz, T.; Haase, A. Fabrication of NMR-Microsensors for nano-liter sample volumes. Microelectron. Eng. 2000, 53, 517-519. [CrossRef]

131. Van Bentum, P.J.M.; Janssen, J.W.G.; Kentgens, A.P.M. Towards nuclear magnetic resonance $\mu$-spectroscopy and $\mu$-imaging. Analyst 2004, 129, 793-803. [CrossRef] [PubMed]

132. Maguire, Y.; Chuang, I.L.; Zhang, S.; Gershenfeld, N. Ultra-small-sample molecular structure detection using microslot waveguide nuclear spin resonance. Proc. Natl. Acad. Sci. USA 2007, 104, 9198-9203. [CrossRef]

133. Van Bentum, P.J.M.; Janssen, J.W.G.; Kentgens, A.P.M.; Bart, J.; Gardeniers, J.G.E. Stripline probes for nuclear magnetic resonance. J. Magn. Reson. 2007, 189, 104-113. [CrossRef]

134. Bart, J.; Janssen, J.W.G.; van Bentum, P.J.M.; Kentgens, A.P.M.; Gardeniers, J.G.E. Optimization of stripline-based microfluidic chips for high-resolution NMR. J. Magn. Reson. 2009, 201, 175-185. [CrossRef] [PubMed]

135. Oosthoek de Vries, A.J.; Bart, J.; Tiggelaar, R.M.; Janssen, J.W.G.; van Bentum, P.J.M.; Gardeniers, H.J.G.E.; Kentgens, A.P.M. Continuous Flow ${ }^{1} \mathrm{H}$ and ${ }^{13} \mathrm{C}$ NMR Spectroscopy in Micro-fluidic Stripline NMR Chips. Anal. Chem. 2017, 89, 2296-2303. [CrossRef] [PubMed] 
136. Sidles, J.A. Noninductive detection of single-proton magnetic resonance. Appl. Phys. Lett. 1991, 58, 2854-2856. [CrossRef]

137. Sidles, J.A.; Garbini, J.L.; Bruland, K.J.; Rugar, D.; Züger, O.; Hoen, S.; Yannoni, C.S. Magnetic resonance force microscopy. Rev. Mod. Phys. 1995, 67, 249-265. [CrossRef]

138. Rugar, D.; Budakian, R.; Mamin, H.J.; Chui, B.W. Single spin detection by magnetic resonance force microscopy. Nature 2004, 430, 329-332. [CrossRef] [PubMed]

139. Rugar, D.; Yannoni, C.S.; Sidles, J.A. Mechanical detection of magnetic resonance. Nature 1992, 360, 563. [CrossRef]

140. Rugar, D.; Zuger, O.; Hoen, S.; Yannoni, C.S.; Vieth, H.-M.; Kendrick, R.D. Force Detection of Nuclear Magnetic Resonance. Science 1994, 264, 1560-1563. [CrossRef]

141. Mamin, H.J.; Oosterkamp, T.H.; Poggio, M.; Degen, C.L.; Rettner, C.T.; Rugar, D. Isotope-Selective Detection and Imaging of Organic Nanolayers. Nano Lett. 2009, 9, 3020-3024. [CrossRef]

142. Leskowitz, G.M.; Madsen, L.A.; Weitekamp, D.P. Force-detected magnetic resonance without field gradients. Solid State Nucl. Magn. Reson. 1998, 11, 73-86. [CrossRef]

143. Degen, C.L.; Poggio, M.; Mamin, H.J.; Rettner, C.T.; Rugar, D. Nanoscale magnetic resonance imaging. Proc. Natl. Acad. Sci. USA 2009, 106, 1313-1317. [CrossRef] [PubMed]

144. Verhagen, R.; Wittlin, A.; Hilbers, C.W.; van Kempen, H.; Kentgens, A.P.M. Spatially Resolved Spectroscopy and Structurally Encoded Imaging by Magnetic Resonance Force Microscopy of Quadrupolar Spin Systems. J. Am. Chem. Soc. 2002, 124, 1588-1589. [CrossRef] [PubMed]

145. Nestle, N.; Schaff, A.; Veeman, W.S. Mechanically detected NMR, an evaluation of the applicability for chemical investigations. Prog. Nucl. Magn. Reson. Spectrosc. 2001, 38, 1-35. [CrossRef]

146. Jancso, A.; Correia, J.G.; Gottberg, A.; Schell, J.; Stachura, M.; Szunyogh, D.; Pallada, S.; Lupascu, D.C.; Kowalska, M.; Hemmingsen, L. TDPAC and $\beta$-NMR applications in chemistry and biochemistry. J. Phys. G Nucl. Part. Phys. 2017, $44,064003$. [CrossRef]

147. Neugart, R.; Balabanski, D.L.; Blaum, K.; Borremans, D.; Himpe, P.; Kowalska, M.; Lievens, P.; Mallion, S.; Neyens, G.; Vermeulen, N.; et al. Precision Measurement of ${ }^{11} \mathrm{Li}$ Moments: Influence of Halo Neutrons on the ${ }^{9}$ Li Core. Phys. Rev. Lett 2008, 101, 132502. [CrossRef]

148. Keim, M.; Georg, U.; Klein, A.; Neugart, R.; Neuroth, M.; Wilbert, S.; Lievens, P.; Vermeeren, L.; Brown, B.A. ISOLDE Collaboration. Measurement of the electric quadrupole moments of ${ }^{26-29}$ Na. Eur. Phys. J. A 2000, 8, 31-40. [CrossRef]

149. McKenzie, I.; Chai, Y.; Cortie, D.L.; Forrest, J.A.; Fujimoto, D.; Karner, V.L.; Kiefl, R.F.; Levy, C.D.P.; MacFarlane, W.A.; McFadden, R.M.L.; et al. Direct measurements of the temperature, depth and processing dependence of phenyl ring dynamics in polystyrene thin films by $\beta$-detected NMR. Soft Matter 2018, 14, 7324-7334. [CrossRef]

150. Brewer, W.D. Recent developments in radiative detection of nuclear magnetic resonance. Hyperfine Interact 1982, 12, 173-210. [CrossRef]

151. Winnefeld, H.; Czanta, M.; Fahsold, G.; Jänsch, H.J.; Kirchner, G.; Mannstadt, W.; Paggel, J.J.; Platzer, R.; Schillinger, R.; Veith, R.; et al. Electron localization in $(7 \times 7)$ re-constructed and hydrogen-covered $\mathrm{Si}(111)$ surfaces as seen by NMR on adsorbed Li. Phys. Rev. B 2002, 65, 195319. [CrossRef]

152. Koumoulis, D.; Morris, G.D.; He, L.; Kou, X.; King, D.; Wang, D.; Hossain, M.D.; Wang, K.L.; Fiete, G.A.; Kanatzidis, M.G.; et al. Nanoscale $\beta$-nuclear magnetic resonance depth imaging of topological insulators. Proc. Natl. Acad. Sci. USA 2015, 112, E3645-E3650. [CrossRef] [PubMed]

153. Mansour, A.I.; Morris, G.D.; Salman, Z.; Chow, K.H.; Dunlop, T.; Jung, J.; Fan, I.; MacFarlane, W.A.; Kiefl, R.F.; Parolin, T.J.; et al. Development of the ${ }^{8} \mathrm{Li}$ cross-relaxation technique: Applications in semiconductors and other condensed matter systems. Physica B Condensed Matter 2007, 401-402, 662-665. [CrossRef]

154. Chow, K.H.; Salman, Z.; Kiefl, R.F.; MacFarlane, W.A.; Levy, C.D.P.; Amaudruz, P.; Baartman, R.; Chakhalian, J.; Daviel, S.; Hirayama, Y.; et al. The new $\beta-N M R$ facility at TRI-UMF and applications in semiconductors. Physica B Condensed Matter 2003, 340-342, 1151-1154. [CrossRef]

155. Cortie, D.L.; Buck, T.; Dehn, M.H.; Karner, V.L.; Kiefl, R.F.; Levy, C.D.P.; McFadden, R.M.L.; Morris, G.D.; McKenzie, I.; Pearson, M.R.; et al. $\beta$-NMR Investigation of the Depth-Dependent Magnetic Properties of an Antiferromagnetic Surface. Phys. Rev. Lett. 2016, 116, 106103. [CrossRef]

156. Morris, G.D.; MacFarlane, W.A.; Chow, K.H.; Salman, Z.; Arseneau, D.J.; Daviel, S.; Hatakeyama, A.; Kreitzman, S.R.; Levy, C.D.P.; Poutissou, R.; et al. Depth-Controlled $\beta$-NMR of ${ }^{8} \mathrm{Li}$ in a Thin Silver Film. Phys. Rev. Lett. 2004, 93, 157601. [CrossRef] [PubMed]

157. McKenzie, I.; Daley, C.R.; Kiefl, R.F.; Levy, C.D.P.; MacFarlane, W.A.; Morris, G.D.; Pearson, M.R.; Wang, D.; Forrest, J.A. Enhanced high-frequency molecular dynamics in the near-surface region of polystyrene thin films observed with $\beta$-NMR. Soft Matter 2015, 11, 1755-1761. [CrossRef] [PubMed]

158. McKenzie, I.; Harada, M.; Kiefl, R.F.; Levy, C.D.P.; MacFarlane, W.A.; Morris, G.D.; Ogata, S.-I.; Pearson, M.R.; Sugiyama, J. $\beta$-NMR Measurements of Lithium Ion Transport in Thin Films of Pure and Lithium-Salt-Doped Poly(ethylene oxide). J. Am. Chem. Soc. 2014, 136, 7833-7836. [CrossRef]

159. Rossini, A.J.; Zagdoun, A.; Lelli, M.; Lesage, A.; Copéret, C.; Emsley, L. Dynamic Nuclear Polarization Surface Enhanced NMR Spectroscopy. Acc. Chem. Res. 2013, 46, 1942-1951. [CrossRef]

160. Elena, B.; Lesage, A.; Steuernagel, S.; Böckmann, A.; Emsley, L. Proton to Carbon-13 INEPT in Solid-State NMR Spectroscopy. J. Am. Chem. Soc. 2005, 127, 17296-17302. [CrossRef] 
161. Agarwal, V.; Reif, B. Residual methyl protonation in perdeuterated proteins for multi-dimensional correlation experiments in MAS solid-state NMR spectroscopy. J. Magn. Reson. 2008, 194, 16-24. [CrossRef]

162. Baldus, M.; Meier, B.H. Total Correlation Spectroscopy in the Solid State. The Use of Scalar Couplings to Determine the Through-Bond Connectivity. J. Magn. Reson. Ser. A 1996, 121, 65-69. [CrossRef]

163. Phyo, P.; Hong, M. Fast MAS ${ }^{1} \mathrm{H}-{ }^{13} \mathrm{C}$ correlation NMR for structural investigations of plant cell walls. J. Biomol. NMR 2019, 73, 661-674. [CrossRef] [PubMed]

164. Mance, D.; Sinnige, T.; Kaplan, M.; Narasimhan, S.; Daniëls, M.; Houben, K.; Baldus, M.; Weingarth, M. An Efficient Labelling Approach to Harness Backbone and Side-Chain Protons in ${ }^{1} \mathrm{H}$-Detected Solid-State NMR Spectroscopy. Angew. Chem. 2015, 54, 15799-15803. [CrossRef] [PubMed]

165. Baker, L.A.; Sinnige, T.; Schellenberger, P.; de Keyzer, J.; Siebert, C.A.; Driessen, A.J.M.; Baldus, M.; Grünewald, K. Combined ${ }^{1}$ H-Detected Solid-State NMR Spectroscopy and Electron Cryotomography to Study Membrane Proteins across Resolutions in Native Environments. Structure 2018, 26, 161-170.e3. [CrossRef]

166. Roos, M.; Mandala, V.S.; Hong, M. Determination of Long-Range Distances by Fast Magic-Angle-Spinning Radiofrequency-Driven ${ }^{19} \mathrm{~F}-{ }^{19} \mathrm{~F}$ Dipolar Recoupling NMR. J. Phys. Chem. B 2018, 122, 9302-9313. [CrossRef] [PubMed]

167. Wang, M.; Lu, M.; Fritz, M.P.; Quinn, C.M.; Byeon, I.-J.L.; Byeon, C.-H.; Struppe, J.; Maas, W.; Gronenborn, A.M.; Polenova, T. Fast Magic-Angle Spinning ${ }^{19}$ F NMR Spectroscopy of HIV-1 Capsid Protein Assemblies. Angew. Chem. 2018, 57, 16375-16379. [CrossRef]

168. Shcherbakov, A.A.; Mandala, V.S.; Hong, M. High-Sensitivity Detection of Nanometer ${ }^{1} \mathrm{H}-{ }^{19}$ F Distances for Protein Structure Determination by ${ }^{1} \mathrm{H}$-Detected Fast MAS NMR. J. Phys. Chem. B 2019, 123, 4387-4391. [CrossRef]

169. Fry, R.A.; Tsomaia, N.; Pantano, C.G.; Mueller, K.T. ${ }^{19}$ F MAS NMR Quantification of Accessible Hydroxyl Sites on Fiberglass Surfaces. J. Am. Chem. Soc. 2003, 125, 2378-2379. [CrossRef]

170. Venkatesh, A.; Hanrahan, M.P.; Rossini, A.J. Proton detection of MAS solid-state NMR spectra of half-integer quadrupolar nuclei. Solid State Nucl. Magn. Reson. 2017, 84, 171-181. [CrossRef]

171. Pöppler, A.-C.; Demers, J.-P.; Malon, M.; Singh, A.P.; Roesky, H.W.; Nishiyama, Y.; Lange, A. Ultrafast Magic-Angle Spinning: Benefits for the Acquisition of Ultrawide-Line NMR Spectra of Heavy Spin-1/2 Nuclei. ChemPhysChem 2016, 17, 812-816. [CrossRef]

172. Iwasa, Y.; Bascunan, J.; Hahn, S.; Voccio, J.; Kim, Y.; Lecrevisse, T.; Song, J.; Kajikawa, K. A High-Resolution 1.3-GHz/54-mm LTS/HTS NMR Magnet. IEEE Trans. Appl. Supercond 2015, 25, 1-5. [CrossRef]

173. Gan, Z.; Hung, I.; Wang, X.; Paulino, J.; Wu, G.; Litvak, I.M.; Gor'kov, P.L.; Brey, W.W.; Lendi, P.; Schiano, J.L.; et al. NMR spectroscopy up to $35.2 \mathrm{~T}$ using a series-connected hybrid magnet. J. Magn. Reson. 2017, 284, 125-136. [CrossRef]

174. Bryce, D.L. New frontiers for solid-state NMR across the periodic table: A snapshot of mod-ern techniques and instrumentation. Dalton Trans. 2019, 48, 8014-8020. [CrossRef]

175. Gan, Z.; Gor'kov, P.; Cross, T.A.; Samoson, A.; Massiot, D. Seeking Higher Resolution and Sensitivity for NMR of Quadrupolar Nuclei at Ultrahigh Magnetic Fields. J. Am. Chem. Soc. 2002, 124, 5634-5635. [CrossRef]

176. Madsen, R.S.K.; Qiao, A.; Sen, J.; Hung, I.; Chen, K.; Gan, Z.; Sen, S.; Yue, Y. Ultrahigh-field ${ }^{67}$ Zn NMR reveals short-range disorder in zeolitic imidazolate framework glasses. Science 2020, 367, 1473-1476. [CrossRef] [PubMed]

177. Ashbrook, S.E.; Sneddon, S. New Methods and Applications in Solid-State NMR Spectroscopy of Quadrupolar Nuclei. J. Am. Chem. Soc. 2014, 136, 15440-15456. [CrossRef] [PubMed]

178. Hassan, A.; Quinn, C.M.; Struppe, J.; Sergeyev, I.V.; Zhang, C.; Guo, C.; Runge, B.; Theint, T.; Dao, H.H.; Jaroniec, C.P.; et al. Sensitivity boosts by the CPMAS CryoProbe for challenging biological assemblies. J. Magn. Reson. 2020, 311, 106680. [CrossRef] [PubMed]

179. Stebbins, J.F. Anionic speciation in sodium and potassium silicate glasses near the metasilicate $\left(\left[\mathrm{Na}, \mathrm{K}_{2} 2 \mathrm{SiO}_{3}\right) \mathrm{composition:}^{29} \mathrm{Si}\right.$, ${ }^{17} \mathrm{O}$, and ${ }^{23} \mathrm{Na}$ MAS NMR. J. Non-Cryst. Solids X 2020, 6, 100049. [CrossRef]

180. Qi, G.; Wang, Q.; Xu, J.; Wu, Q.; Wang, C.; Zhao, X.; Meng, X.; Xiao, F.; Deng, F. Direct observation of tin sites and their reversible interconversion in zeolites by solid-state NMR spectroscopy. Commun. Chem. 2018, 1, 22. [CrossRef]

181. Widdifield, C.M. Applications of Solid-State ${ }^{43}$ Ca Nuclear Magnetic Resonance: Superconductors, Glasses, Biomaterials, and NMR Crystallography. In Annual Reports on NMR Spectroscopy; Elsevier: Amsterdam, The Netherlands, 2017; pp. 227-363. [CrossRef]

182. Laurencin, D.; Smith, M.E. Development of ${ }^{43}$ Ca solid state NMR spectroscopy as a probe of local structure in inorganic and molecular materials. Prog. Nucl. Magn. Reson. Spectrosc. 2013, 68, 1-40. [CrossRef] [PubMed]

183. Bryce, D.L. Calcium binding environments probed by ${ }^{43}$ Ca NMR spectroscopy. Dalton Trans. 2010, 39, 8593-8602. [CrossRef]

184. Leroy, C.; Bryce, D.L. Recent advances in solid-state nuclear magnetic resonance spectroscopy of exotic nuclei. Prog. Nucl. Magn. Reson. Spectrosc. 2018, 109, 160-199. [CrossRef] [PubMed]

185. Natusch, D.F.S. Carbon-13 intensity problem. Elimination of the Overhauser effect with an added paramagnetic species. J. Am. Chem. Soc. 1971, 93, 2566-2567. [CrossRef]

186. Gansow, O.A.; Burke, A.R.; Vernon, W.D. Temperature-dependent carbon-13 nuclear magnetic resonance spectra of the h5cyclopentadienyliron dicarbonyl dimer, an application of a shiftless relaxation reagent. J. Am. Chem. Soc. 1972, 94, $2550-2552$. [CrossRef] 
187. Long, H.W.; Tycko, R. Biopolymer Conformational Distributions from Solid-State NMR: $\alpha$-Helix and 310-Helix Contents of a Helical Peptide. J. Am. Chem. Soc. 1998, 120, 7039-7048. [CrossRef]

188. Meinhold, R.H.; MacKenzie, K.J.D. Effect of lanthanides on the relaxation rates of ${ }^{89} \mathrm{Y}$ and ${ }^{29}$ Si in yttrium silicon oxynitride phases. Solid State Nucl. Magn. Reson. 1995, 5, 151-161. [CrossRef]

189. Nishiyama, Y.; Fukushima, T.; Fukuchi, M.; Fujimura, S.; Kaji, H. Sensitivity boosting in solid-state NMR of thin organic semiconductors by a paramagnetic dopant of copper phthalo-cyanine. Chem. Phys. Lett. 2013, 556, 195-199. [CrossRef]

190. Wang, Z.; Hanrahan, M.P.; Kobayashi, T.; Perras, F.A.; Chen, Y.; Engelke, F.; Reiter, C.; Purea, A.; Rossini, A.J.; Pruski, M. Combining fast magic angle spinning dynamic nuclear polarization with indirect detection to further enhance the sensitivity of solid-state NMR spectroscopy. Solid State Nucl. Magn. Reson. 2020, 109, 101685. [CrossRef] [PubMed]

191. Berruyer, P.; Björgvinsdóttir, S.; Bertarello, A.; Stevanato, G.; Rao, Y.; Karthikeyan, G.; Casano, G.; Ouari, O.; Lelli, M.; Reiter, C.; et al. Dynamic Nuclear Polarization Enhancement of 200 at 21.15 T Enabled by 65 kHz Magic Angle Spinning. J. Phys. Chem. Lett. 2020, 11, 8386-8391. [CrossRef]

192. Hoehne, F.; Dreher, L.; Franke, D.P.; Stutzmann, M.; Vlasenko, L.S.; Itoh, K.M.; Brandt, M.S. Submillisecond Hyperpolarization of Nuclear Spins in Silicon. Phys. Rev. Lett. 2015, 114, 117602. [CrossRef]

193. Can, T.V.; Walish, J.J.; Swager, T.M.; Griffin, R.G. Time domain DNP with the NOVEL sequence. J. Chem. Phys. 2015, $143,054201$. [CrossRef]

194. Griffin, R.G. Clear signals from surfaces. Nature 2010, 468, 381-382. [CrossRef]

195. W.-Liao, C.; Ghaffari, B.; Gordon, C.P.; Xu, J.; Copéret, C. Dynamic Nuclear Polarization Surface Enhanced NMR spectroscopy (DNP SENS): Principles, protocols, and practice. Curr. Opin. Colloid Interface Sci. 2018, 33, 63-71. [CrossRef]

196. Lesage, A.; Lelli, M.; Gajan, D.; Caporini, M.A.; Vitzthum, V.; Miéville, P.; Alauzun, J.; Rous-sey, A.; Thieuleux, C.; Mehdi, A.; et al. Surface Enhanced NMR Spectroscopy by Dynamic Nuclear Polarization. J. Am. Chem. Soc. 2010, 132, 15459-15461. [CrossRef]

197. Lee, S. Sensitive detection of NMR for thin films. Solid State Nucl. Magn. Reson. 2015, 71, 1-10. [CrossRef] [PubMed]

198. Kärger, J.; Avramovska, M.; Freude, D.; Haase, J.; Hwang, S.; Valiullin, R. Pulsed field gradient NMR diffusion measurement in nanoporous materials. Adsorption 2021, 27, 453-484. [CrossRef]

199. Nieuwendaal, R.C.; Ro, H.W.; Germack, D.S.; Kline, R.J.; Toney, M.F.; Chan, C.K.; Agrawal, A.; Gundlach, D.; VanderHart, D.L.; Delongchamp, D.M. Measuring Domain Sizes and Compositional Heterogeneities in P3HT-PCBM Bulk Heterojunction Thin Films with ${ }^{1} \mathrm{H}$ Spin Diffusion NMR Spectroscopy. Adv. Funct. Mater 2012, 22, 1255-1266. [CrossRef]

200. Sel, O.; To Thi Kim, L.; Debiemme-Chouvy, C.; Gabrielli, C.; Laberty-Robert, C.; Perrot, H. Determination of the Diffusion Coefficient of Protons in Nafion Thin Films by ac Electrogravimetry. Langmuir 2013, 29, 13655-13660. [CrossRef]

201. Han, X.; Xu, K.; Taratula, O.; Farsad, K. Applications of nanoparticles in biomedical imaging. Nanoscale 2019, 11, 799-819. [CrossRef] [PubMed]

202. Mariette, F. Modern Magnetic Resonance; Webb, G.A., Ed.; Springer International Publishing: Cham, Switzerland, 2017 ; pp. 1-23.

203. Zhang, J.; MacGregor, R.P.; Balcom, B.J. Liquid crystal diffusion in thin films investigated by PFG magnetic resonance and magnetic resonance imaging. Chem. Phys. Lett. 2008, 461, 106-110. [CrossRef]

204. Mens, R.; Adriaensens, P.; Lutsen, L.; Swinnen, A.; Bertho, S.; Ruttens, B.; D’Haen, J.; Manca, J.; Cleij, T.; Vanderzande, D.; et al. NMR study of the nanomorphology in thin films of polymer blends used in organic PV devices: MDMO-PPV/PCBM. J. Polym. Sci. Part A Polym. Chem. 2008, 46, 138-145. [CrossRef]

205. Koller, H.; Weiß, M. Solid State NMR of Porous Materials. In Solid State NMR; Chan, J.C.C., Ed.; Springer: Berlin/Heidelberg, Germany, 2011; pp. 189-227. [CrossRef]

206. Borisov, A.S.; Hazendonk, P.; Hayes, P.G. Solid-State Nuclear Magnetic Resonance Spectroscopy: A Review of Modern Techniques and Applications for Inorganic Polymers. J. Inorg. Organomet. Polym. 2010, 20, 183-212. [CrossRef]

207. Knitsch, R.; Brinkkötter, M.; Wiegand, T.; Kehr, G.; Erker, G.; Hansen, M.R.; Eckert, H. Solid-State NMR Techniques for the Structural Characterization of Cyclic Aggregates Based on Borane-Phosphane Frustrated Lewis Pairs. Molecules 2020, 25, 1400. [CrossRef] [PubMed]

208. Van der Wel, P.C.A. New applications of solid-state NMR in structural biology. Emerg. Top. Life Sci. 2018, 2, 57-67. [CrossRef]

209. Rodin, V.V. NMR techniques in studying water in biotechnological systems. Biophys. Rev. 2020, 12, 683-701. [CrossRef] [PubMed]

210. El Hariri El Nokab, M.; van der Wel, P.C.A. Use of solid-state NMR spectroscopy for investigating polysaccharide-based hydrogels: A review. Carbohydr. Polym. 2020, 240, 116276. [CrossRef] [PubMed]

211. Krushelnitsky, A.; Reichert, D.; Saalwächter, K. Solid-State NMR Approaches to Internal Dynamics of Proteins: From Picoseconds to Microseconds and Seconds. Acc. Chem. Res. 2013, 46, 2028-2036. [CrossRef] [PubMed]

212. Molugu, T.R.; Lee, S.; Brown, M.F. Concepts and Methods of Solid-State NMR Spectroscopy Applied to Biomembranes. Chem. Rev. 2017, 117, 12087-12132. [CrossRef]

213. Zhao, W.; Fernando, L.D.; Kirui, A.; Deligey, F.; Wang, T. Solid-state NMR of plant and fungal cell walls: A critical review. Solid State Nucl. Magn. Reson. 2020, 107, 101660. [CrossRef]

214. Simpson, A.J.; Simpson, M.J.; Soong, R. Environmental Nuclear Magnetic Resonance Spectroscopy: An Overview and a Primer. Anal. Chem. 2018, 90, 628-639. [CrossRef]

215. Brunner, E.; Rauche, M. Solid-state NMR spectroscopy: An advancing tool to analyse the structure and properties of metal-organic frameworks. Chem. Sci. 2020, 11, 4297-4304. [CrossRef] 
216. Piveteau, L.; Morad, V.; Kovalenko, M.V. Solid-State NMR and NQR Spectroscopy of Lead-Halide Perovskite Materials. J. Am. Chem. Soc. 2020, 142, 19413-19437. [CrossRef] [PubMed]

217. Seifrid, M.; Reddy, G.N.M.; Chmelka, B.F.; Bazan, G.C. Insight into the structures and dynamics of organic semiconductors through solid-state NMR spectroscopy. Nat. Rev. Mater. 2020, 5, 910-930. [CrossRef]

218. Marchetti, A.; Chen, J.; Pang, Z.; Li, S.; Ling, D.; Deng, F.; Kong, X. Understanding Surface and Interfacial Chemistry in Functional Nanomaterials via Solid-State NMR. Adv. Mater. 2017, 29, 1605895. [CrossRef] [PubMed] 